\title{
Lower Palaeozoic stratigraphy of the East Greenland Caledonides
}

\author{
M. Paul Smith, Jan Audun Rasmussen, Steve Robertson, A.K. Higgins and A. Graham Leslie
}

\begin{abstract}
The Lower Palaeozoic stratigraphy of the East Greenland Caledonides, from the fjord region of North-East Greenland northwards to Kronprins Christian Land, is reviewed and a number of new lithostratigraphical units are proposed. The Slottet Formation (new) is a Lower Cambrian quartzite unit, containing Skolithos burrows, that is present in the Målebjerg and Eleonore Sø tectonic windows, in the nunatak region of North-East Greenland. The unit is the source of common and often-reported glacial erratic boulders containing Skolithos that are distributed throughout the fjord region. The Målebjerg Formation (new) overlies the Slottet Formation in the tectonic windows, and comprises limestones and dolostones of assumed Cambrian-Ordovician age. The Lower Palaeozoic succession of the fjord region of East Greenland (dominantly limestones and dolostones) is formally placed in the Kong Oscar Fjord Group (new). Amendments are proposed for several existing units in the Kronprins Christian Land and Lambert Land areas, where they occur in autochthonous, parautochthonous and allochthonous settings.
\end{abstract}

Keywords: Early Palaeozoic, North-East Greenland, stratigraphy.

M.P.S., Lapworth Museum, School of Geography, Earth and Environmental Sciences, University of Birmingham,
Edgbaston, Birmingham B15 2TT, UK. E-mail: m.p.smith@bham.ac.uk,
J.A.R. \& A.K.H., Geological Survey of Denmark and Greenland, Øster Voldgade 10, DK-1350 Copenhagen K,
Denmark.
S.R. (deceased) \& A.G.L., British Geological Survey, Murchison House, West Mains Road, Edinburgh EH93LA, UK.

The East Greenland Caledonides extend for over 1300 $\mathrm{km}$ between Scoresby Sund $\left(70^{\circ} \mathrm{N}\right)$ and Kronprins Christian Land $\left(81^{\circ} 30^{\prime} \mathrm{N}\right)$, cropping out in an ice-free coastal strip of variable width (Fig. 1). In the south, the exposed width of the orogen is $300 \mathrm{~km}$, but in the north this is reduced to less than $100 \mathrm{~km}$. The orogen has been the subject of a series of systematic mapping programmes by the Survey since 1968, supplementing and revising work by other groups, most notably Lauge Koch's long series of geological expeditions between 1926 and 1958 (see Haller 1971). This paper documents the key stratigraphical observations on Lower Palaeozoic rocks made during expeditions from 1993 to 1995 by the former Geological Survey of Greenland (GGU) to Kronprins Christian Land and Lambert Land $\left(78^{\circ}-82^{\circ} \mathrm{N}\right)$, and the 1997-1998 field work by the Survey in the Kong Oscar Fjord region $\left(72^{\circ}-75^{\circ} \mathrm{N}\right)$. A number of new Lower Palaeozoic lithostratigraphical units are proposed on the basis of this work and amendments are proposed for some existing units.

The Lower Palaeozoic sediments of Kronprins Christian Land and Lambert Land (Fig. 2) were deposited on a subtidal to peritidal platform that constituted the south-easternmost part of the Franklinian Basin (Higgins et al. 1991), and lay at a marked inflexion of the Laurentian margin where it turns through $90^{\circ}$ between the present-day E-W-trending coast of North Greenland and the N-S-trending coast of East Greenland. The stratigraphy erected in the Caledonian foreland of eastern North Greenland (Peary Land and western Kronprins Christian Land; Peel 1985; Higgins 


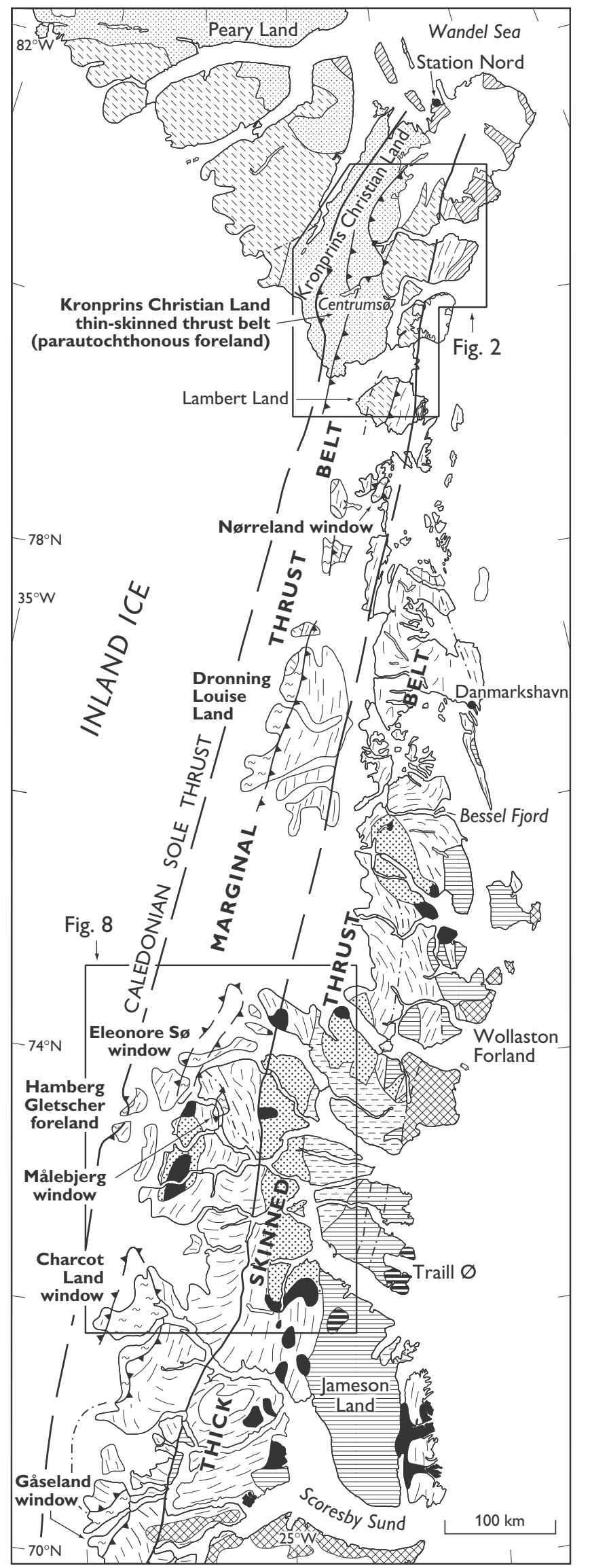

POST-CALEDONIAN

Palaeogene basalts

릴 Palaeogene intrusions

Wandel Sea Basin:

Carboniferous-Palaeogene sediments

East Greenland basins:

Carboniferous-Cretaceous sediments

\section{LATE TO POST-CALEDONIAN}

Devonian - continental sediments

\section{CALEDONIAN OROGENIC BELT}

1 Late to post-kinematic granites

Neoproterozoic-Ordovician

sediments (East Greenland)

Neoproterozoic-Silurian sediments

(eastern North Greenland)

Palaeo-Mesoproterozoic sediments and basalts (eastern North Greenland)

Crystalline complexes and sediments (Archaean-Mesoproterozoic)

\section{CALEDONIAN FORELAND}
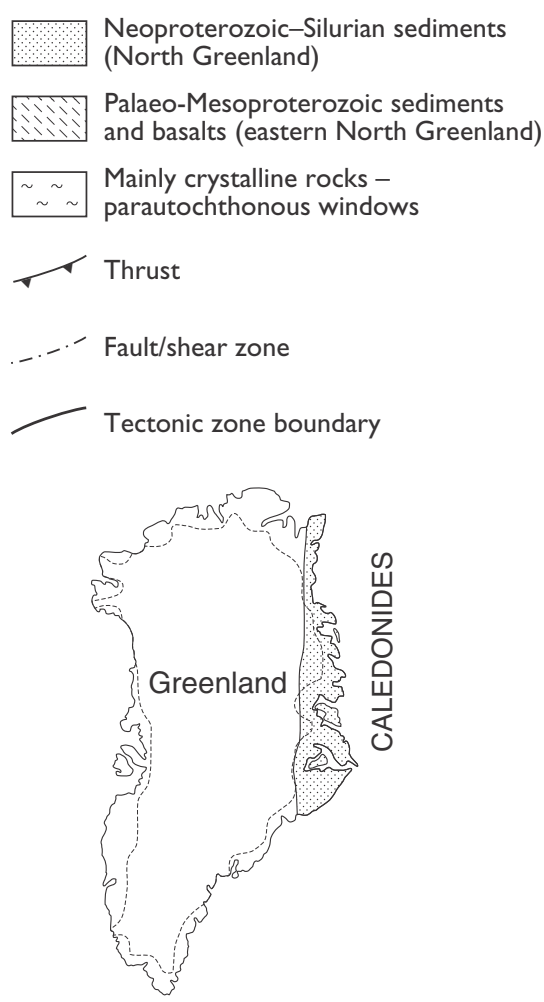

Fig. 1. Geological map of the East Greenland Caledonides, showing location of the foreland windows in the western marginal thrust belt. Modified from Higgins \& Leslie (2000). Frames indicate the regions shown at larger scales in Figs 2 and 8. 
et al. 1991; Smith \& Bjerreskov 1994) can, to a significant degree, be applied to the successions farther to the east and south within the study area (Figs 2, 3), although many of the units differ in detail. This region is the only part of the Franklinian Basin to have been subsequently affected by the Caledonian orogeny, and the Lower Palaeozoic units described here occur both in the foreland and in the thin-skinned parautochthonous fold-and-thrust belt beneath the Vandredalen thrust sheet (Fig. 2; Higgins et al. 2001b).

The Lower Palaeozoic successions of the fjord region of the southern parts of North-East Greenland $\left(72^{\circ}-74^{\circ} 30^{\prime} \mathrm{N}\right.$; see Fig. 8) have been the subject of a more protracted research effort that extends back to the 19th century. The Cambrian-Ordovician of the fjord region has become one of the classic reference areas for this stratigraphical interval, but it was only during the 1997-1998 Survey field seasons that the tectonic context was fully elucidated (Higgins et al. 2004a). It is now clear that the Cambrian-Ordovician of the fjord region, together with the underlying, Neoproterozoic Tillite Group and Eleonore Bay Supergroup, make up the upper part of the highest thrust sheet in the orogen, which has been transported several hundred kilometres from the east-south-east (Higgins \& Leslie 2000; Higgins et al. 2004a). Furthermore, notably different developments of Lower Palaeozoic rocks were discovered cropping out in tectonic windows adjacent to the Inland Ice; the successions within these windows are disturbed by Caledonian deformation, and are interpreted as autochthonous to parautochthonous representatives of the foreland (Smith \& Robertson 1999a, b; Higgins et al. 2004a, b, this volume). The latter are fully documented for the first time here, and provide data critical for interpreting the Lower Palaeozoic evolution of the Iapetus passive margin and its subsequent deformation during the Caledonian orogeny.

\section{Kronprins Christian Land}

The Lower Palaeozoic units cropping out over a $c$. $5000 \mathrm{~km}^{2}$ area in southern Kronprins Christian Land, eastern North Greenland (Figs 2, 3), were mapped and documented in 1993-1995 as part of the 1:500 000 mapping programme carried out by GGU. Within the thin-skinned parautochthonous fold-and-thrust belt forming much of this region (Higgins et al. 2004b, this volume) exposure is often poor due to an extensive cover of recent glacio-fluvial sediments, and the best exposures are on the slopes of the main valleys, with more scattered outcrops on the plateaus. The discontinuous exposure is disrupted by a series of eastward-dipping thrusts with displacements of several hundred metres to a few kilometres. Correlation of superficially similar Middle Ordovician to Silurian sediments in alternating units of peritidal dolostone and subtidal burrow-mottled limestones required detailed sedimentary facies analysis. Macrofaunal biostratigraphy in the field was supplemented by the biostratigraphic analysis of conodonts, which in almost all cases verified the field determinations (Rasmussen \& Smith 2001). Cambrian sediments are restricted to the sandstones of the Kap Holbæk Formation (see below), scattered representatives of which occur in autochthonous, parautochthonous and allochthonous settings.

\section{Kap Holbæk Formation}

revised

History. The Kap Holbæk Formation was first documented by Adams \& Cowie (1953) during a geological reconnaissance around the head of Danmark Fjord, and was informally divided into five members. Fränkl (1954) demonstrated that the unit was also present in Kronprins Christian Land around Sæfaxi Elv, and Hurst \& McKerrow (1985) interpreted it as occurring within thrust sheets north of Romer Sø. Initial biostratigraphical determinations (Peel \& Vidal 1988) concluded that, on the basis of acritarchs, the unit was of latest Vendian (late Ediacaran) age.

Clemmensen \& Jepsen (1992) revised the Hagen Fjord Group of Haller (1961) to encompass a phase of Neoproterozoic shallow marine sedimentation which succeeds the Palaeoproterozoic-Mesoproterozoic Independence Fjord Group and the Mesoproterozoic ZigZag Dal Basalt Formation, and pre-dates Franklinian Basin sedimentation. Since the Kap Holbæk Formation was thought to be of Vendian age, the formation was considered to be representative of the youngest phase of sedimentation in the Hagen Fjord Group basin. However, two schemes of possible stratigraphic correlation could still be used to express the relationship of the Kap Holbæk Formation to the underlying Fyns Sø Formation, with radically different consequences in terms of basin evolution models and correlation with East Greenland.

These alternatives were outlined by Sønderholm \& Jepsen (1991): 


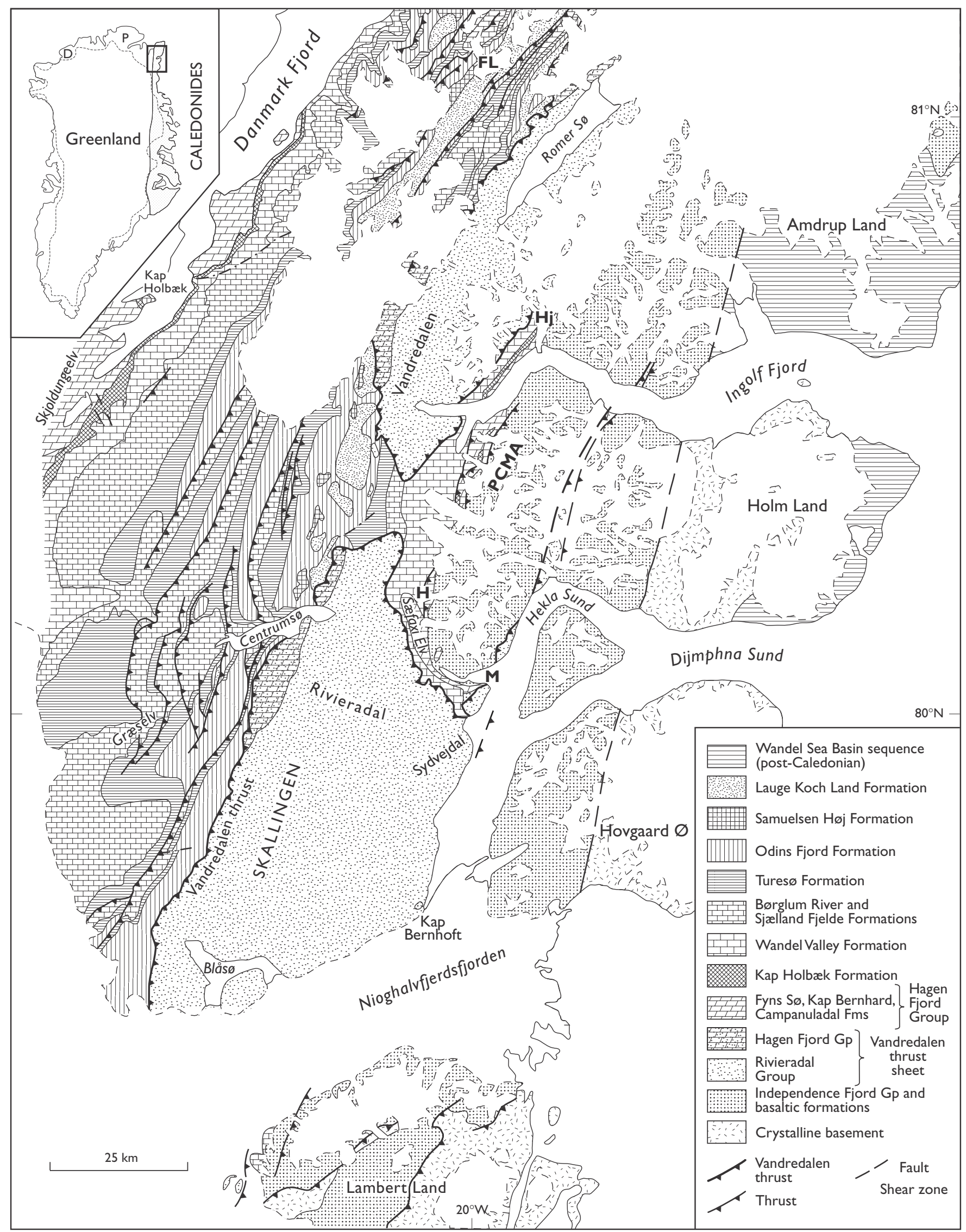


1. The late Ediacaran Kap Holbæk Formation could rest conformably on the Fyns $\$ \varnothing$ Formation, in which case the whole of the Hagen Fjord Group would probably be of Vendian age (Sønderholm \& Jepsen 1991, fig. 18B).

2. The formation could rest disconformably on the Fyns Sø Formation; the latter could then be representative of the late Riphean to Sturtian carbonate developments that characterise the North Atlantic area. In this case, a substantial hiatus would span the Vendian, and the Hagen Fjord Group would be of Riphean to Sturtian age (Sønderholm \& Jepsen 1991, fig. 18A).

The Kap Holbæk Formation overlies stromatolitic dolostones of the Fyns Sø Formation at Kap Holbæk with a well-defined, but in detail obscured, contact. Clues that might have helped to differentiate between these two hypotheses include the occurrence of a single clast of Fyns Sø Formation-like lithology in the Morænes $\varnothing$ Formation, a glacially influenced deposit of presumed Varanger age in central Peary Land (Collinson et al. 1989; Sønderholm \& Jepsen 1991). An additional indication was provided by Fränkl (1955) who had interpreted the Kap Holbæk Formation as being the fill of karstic cavities in the top of the Fyns Sø Formation at a single locality in Sæfaxi Elv.

Field work in Sxefaxi Elv in 1994 confirmed and expanded on Fränkl's observations. The uppermost part of the Fyns Sø Formation was found to contain cave systems, infilled with sandstone, which are of typical phreatic character (Smith et al. 1999). The Fyns Sø Formation is unconformably overlain by the Wandel Valley Formation, which is sandy at the base but passes upwards into typical dolomitic lithofacies of the Danmark Fjord Member. Confirmation of the lithostratigraphical relationships came from a locality at the junction of Hjørnegletscher and Ingolf Fjord; here

\section{Facing page:}

Fig. 2. Geological map of Kronprins Christian Land and Lambert Land; see inset outline map and Fig. 1 for location. The region shows the well-exposed transition from autochthonous foreland in the west around Kap Holbæk and Danmark Fjord, eastwards through a thin-skinned fold-andthrust belt, to the allochthonous Vandredalen thrust sheet and higher thrust sheets. FL, Finderup Land; H, Harefjeld; Hj, Hjørnegletscher; M, Marmorvigen; PCMA, Prinsesse Caroline-Mathilde Alper. On inset map of Greenland; D, Daugaard-Jensen Land; $\mathbf{P}$, Peary Land. the Fyns Sø Formation is overlain by the Kap Holbæk Formation but infilled caves are preserved in the uppermost Fyns Sø Formation (Smith et al. 1999). Deep channels are incised into the top of the latter and both the caves and the channels are infilled by lithofacies that can be directly matched to the lower part of the Kap Holbæk Formation (Smith et al. 1999). The channels and caves constitute one of the most spectacular and well-preserved examples of pre-Carboniferous palaeokarst recorded to date.

The demonstration of a hiatus between the Fyns Sø and Kap Holbæk Formations lends support to correlation alternative 2 above (scheme A of Sønderholm \& Jepsen 1991), which invokes a major time gap between the two units (Fig. 3). Further support comes from the interpretation of Bjørnøya (western Svalbard) as a detached North Greenland terrane (Smith 2000). On Bjørnøya, a carbonate unit similar to the Fyns $\$ \varnothing$ Formation is overlain by a sparse diamictite interpreted as a glacial horizon by Harland et al. (1993), indicating that the carbonate is pre-Vendian. The glacial unit, the Sørhamna Formation, is unconformably overlain by the 'Younger Dolomite', a peritidal dolostone containing a mid-Early Ordovician fauna that is closely comparable with the Wandel Valley Formation (Smith 2000).

Efforts to internationally standardise the position of the Vendian-Cambrian boundary have produced a wealth of biostratigraphic data in recent years. The redefined boundary has the effect of including a considerable time interval, the Nemakit-Daldyn (544-535 Ma), within the Early Cambrian that was previously included within the Neoproterozoic. Furthermore, deep Skolithos burrows are now known to have a first appearance in the Tommotian (mid-Early Cambrian). Their presence close to the base of the Kap Holbæk Formation means that the unit is of Early Cambrian age, and is thus a probable correlative of the Buen Formation of North Greenland, as originally postulated (Peel 1980; Peel et al. 1981; see Fig. 7). Because of the substantial time gap between the Fyns Sø Formation and the Kap Holbæk Formation, probably corresponding to the whole of the Vendian, the younger unit is here removed from the Hagen Fjord Group.

Type section. Kap Holbæk, a headland close to the head of Danmark Fjord on its western side (Fig. 2).

Thickness. Estimates of the thickness of the Kap Holbæk Formation in the vicinity of Danmark Fjord range from 135 m (Adams \& Cowie 1953) to 150 m (Clem- 


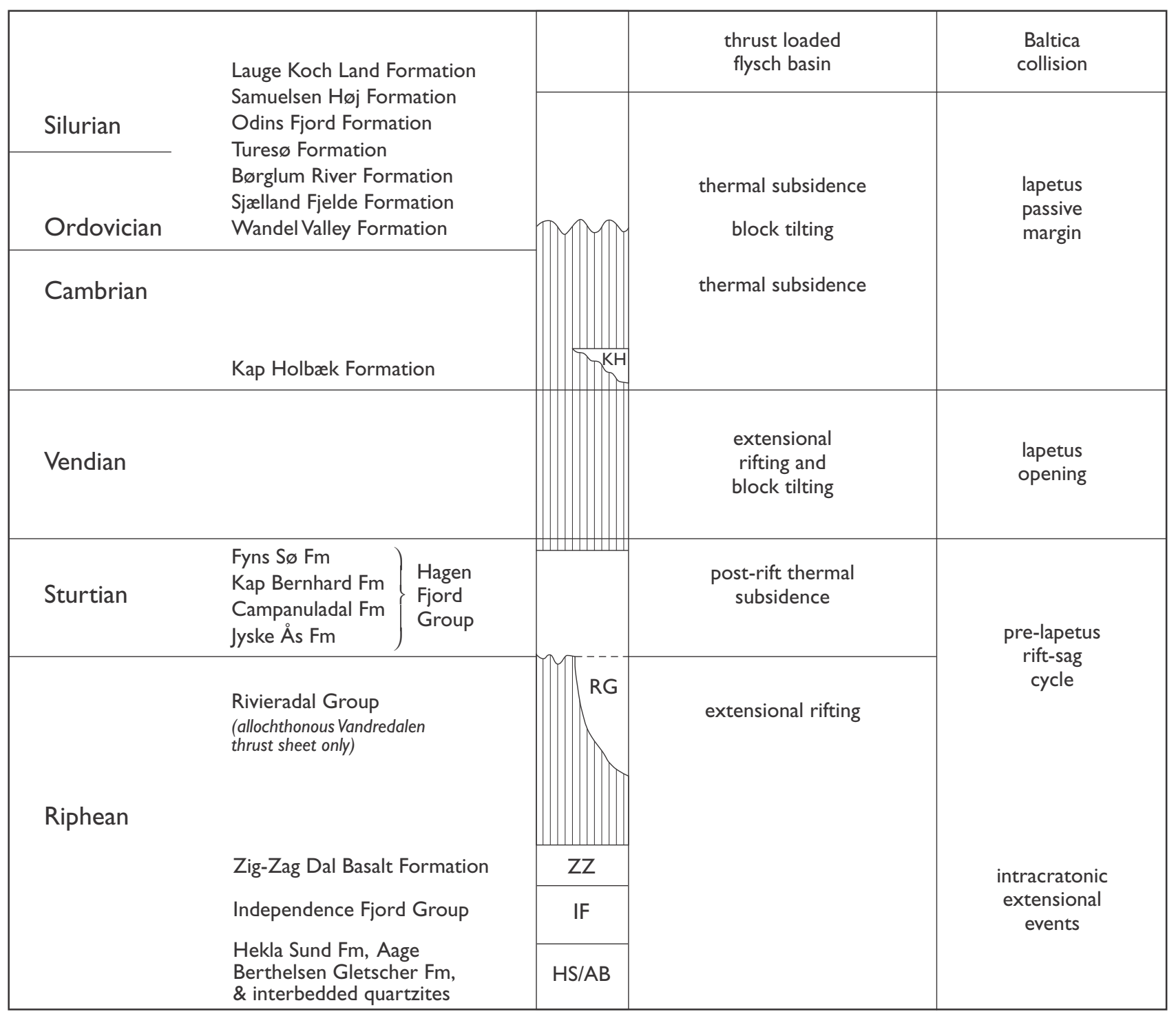

Fig. 3. Pre-Caledonian stratigraphy and tectonic history of Kronprins Christian Land and Lambert Land. Modified from Smith et al. (1999).

mensen \& Jepsen 1992). Farther to the east, in the inner part of Ingolf Fjord, the formation is $180 \mathrm{~m}$ thick but thins southwards, along the western flanks of the Prinsesse Caroline-Mathilde Alper, to zero around Sæfaxi Elv. At Sæfaxi Elv, the Ordovician Wandel Valley Formation rests unconformably on the Fyns Sø Formation and Kap Holbæk sediments are present only as the fill of palaeokarst cavities (Smith et al. 1999). The allochthonous Vandredalen thrust sheet does, however, contain the Kap Holbæk Formation (see below), indicating that the formation was present farther to the east prior to thrusting (Higgins et al. 2001b).
The thinning of the formation to zero is coincident with the position of the rift shoulder of the Hekla Sund basin, the name given by Fränkl (1955) to the half-graben rift basin in which the Neoproterozoic Rivieradal Group accumulated (see also Smith et al. 1999; Higgins et al. 2001b; Smith et al. 2004, this volume), suggesting that the structure continued to exert an influence on sedimentation into the earliest Palaeozoic.

Boundaries. At the type locality, the Kap Holbæk Formation disconformably overlies the Fyns Sø Forma- 


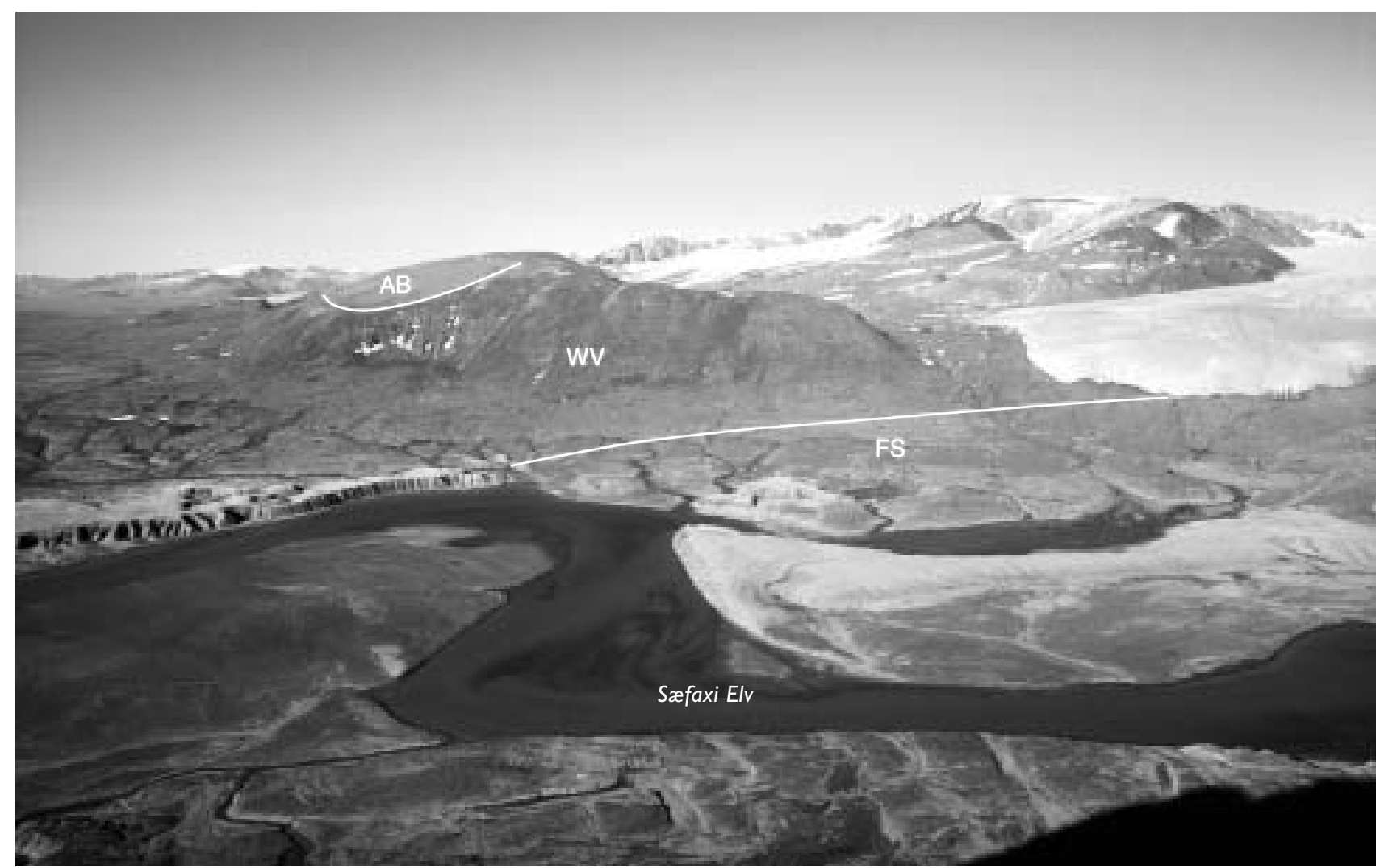

Fig. 4. Harefjeld viewed from the south showing steep or cliff-forming burrow-mottled limestones of the Amdrup Member and Danmarks Fjord Member of the Wandel Valley Formation (WV), which unconformably overlie the Fyns S $\varnothing$ Formation (FS). The recessive pale weathering cap of the hill is the lower part of the Alexandrine Bjerge Member (AB). Sæfaxi Elv in the foreground is 200-400 m wide. Slightly modified from Rasmussen \& Smith (1996).

tion with a hiatus that probably corresponds to most of the Vendian. It is disconformably overlain by the Wandel Valley Formation, which is mid-Early Ordovician in age at the base (Smith 1991; Smith \& Bjerreskov 1994). These relationships pertain throughout the outcrop area, including the palaeokarst localities (Smith et al. 1999).

Distribution. The Kap Holbæk Formation crops out around the southern end of Danmark Fjord, extending southwards along the western side of Skjoldungeelv to the Inland Ice (Fig. 2). Farther east, it crops out along the western side of Ingolf Fjord south of Hjørnegletscher and along the western flanks of the Prinsesse Caroline-Mathilde Alper. At the junction of Hjørnegletscher and Ingolf Fjord it additionally occurs infilling fossil caves in the Fyns Sø Formation, and this is the only context in which it occurs around Sæfaxi Elv. The formation is also present in the frontal part of the Vandredalen thrust sheet in Finderup Land, north of Romer $\$ \varnothing$, where it was first described in the context of the 'Finderup Land Nappe' (Hurst \& McKerrow 1981a, b; Hurst et al. 1985).

Biota and age. Peel \& Vidal (1988) noted a low diversity palynomorph assemblage from the formation and considered that the flora 'in general suggests an age older than Cambrian'. However, as noted above, the base of the Cambrian has now been extended significantly downwards. The sandstones of the Kap Holbæk Formation also contain deep Skolithos burrows which extend vertically for many tens of centimetres (Clemmensen \& Jepsen 1992, fig. 29) and occur to within $30 \mathrm{~m}$ of the base (Adams \& Cowie 1953). The presence of deep Skolithos burrows indicates a Tommotian (Early Cambrian) or younger age (Crimes 1992a). 


\section{Ryder Gletscher Group}

\section{Wandel Valley Formation}

Remarks. The development of the Wandel Valley Formation in southern and eastern Kronprins Christian Land is very similar to that documented in the northern and western parts by Peel \& Smith (1988). In the Sæfaxi Elv - Vandredalen area, the Danmarks Fjord Member $(21 \mathrm{~m})$ is overlain by $200 \mathrm{~m}$ of highly strained burrow-mottled lime mudstones (Amdrup Member) in which the burrows are considerably stretched. This unit is in turn overlain by $115 \mathrm{~m}$ of recessive dolostones of peritidal origin (Alexandrine Bjerge Member). Extensive conodont sampling has verified this lithostratigraphic interpretation.
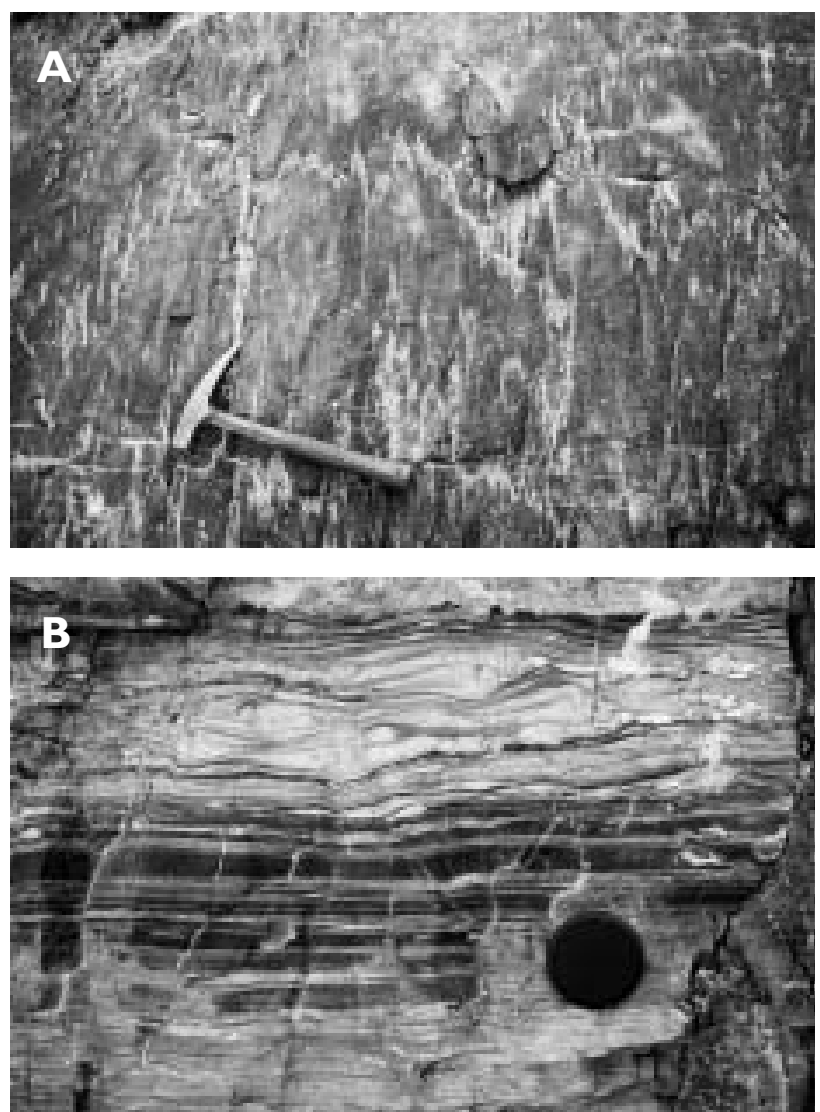

Fig. 5. A: Stylolites in highly strained burrow-mottled facies of the Amdrup Member (Wandel Valley Formation) on Harefjeld. The stylolites are concentrating the buff-weathering, dolomitic burrow fills, and other burrows are highly stretched and flattened. B: Highly strained wavy laminated facies in the basal part of the Wandel Valley Formation, probably representing the Danmarks Fjord Member, in westernmost Lambert Land. Bedding parallel, cylindrical, dolomite-filled burrows are seen in cross-section. Lens cap for scale; from Rasmussen \& Smith (1996).
The three members of the Wandel Valley Formation can be traced along the whole length of Sæfaxi Elv to a point opposite Harefjeld (Fig. 4), the type locality of the 'Harefjeld Formation' of Hurst (1984). The latter unit was considered to be a deep-water equivalent of the Lower Palaeozoic platform succession that was present only in a single thrust sheet, the 'Sæfaxi Elv nappe', with a postulated displacement of over 100 km (Hurst \& McKerrow 1981a, b, 1985; Hurst et al. 1985). However, a number of sections examined around Harefjeld in 1994-1995 demonstrated an identical succession to that in Sæfaxi Elv with sandy Danmarks Fjord Member overlying the Fyns Sø Formation, and in turn overlain by burrow-mottled lime mudstones of the Amdrup Member. Harefjeld is capped by poorly exposed, but distinctive, recessive buff dolostones assigned to the Alexandrine Bjerge Member (Fig. 4). The 'thrust' at the base of the 'Sæfaxi Elv nappe' of Hurst \& McKerrow (1981a, b, 1985) was recognised to be an unconformity with associated palaeokarst development (Rasmussen \& Smith 1996; Smith et al. 1999; see Kap Holbæk Formation above). The succession differs from that in the remainder of Kronprins Christian Land only in exhibiting particularly high levels of strain. Rasmussen \& Smith (1996) therefore proposed the abandonment of the 'Harefjeld Formation'.

The lower member of the Wandel Valley Formation, the Danmarks Fjord Member, varies in thickness from $12 \mathrm{~m}$ around inner Danmark Fjord (Smith \& Peel 1986) to $20-21 \mathrm{~m}$ at Marmorvigen and the inner parts of Ingolf Fjord. The upper part of the unit is strongly brecciated by evaporitic collapse at Ingolf Fjord and Marmorvigen (up to $10 \mathrm{~m}$ in thickness), whereas a $2.5 \mathrm{~m}$ thick breccia occurs in the middle part of the member on the east side of inner Danmark Fjord.

East of Vandredalen, the Danmarks Fjord Member is overlain by highly strained burrow-mottled lime mudstones $(200 \mathrm{~m})$ in which the burrows are considerably stretched (Fig. 5). These have yielded conodonts of late Early Ordovician age and are assigned to the Amdrup Member of the Wandel Valley Formation. This member is in turn overlain by recessive dolostones of peritidal origin $(115 \mathrm{~m})$ containing Whiterockian (Middle Ordovician) conodonts, together indicative of the Alexandrine Bjerge Member (Fig. 4). In summary, all three members of the Wandel Valley Formation in the Sæfaxi Elv - Harefjeld - Ingolf Fjord area are very similar to their development in the Danmark Fjord area on the foreland. Intervals with shallower water lithofacies in the southernmost rep- 
resentatives of the formation in western Lambert Land (see section on Lambert Land below) suggest that a southern or eastern margin of the platform is being approached.

\section{Sjælland Fjelde Formation}

Remarks. The Sjælland Fjelde Formation in the type section near Danmark Fjord is around $100 \mathrm{~m}$ thick and comprises a lower dark grey, burrow-mottled dolostone/limestone unit and an upper, grey dolostone unit (Ineson et al. 1986). The thickness and character of the formation are maintained in the eastern and southern parts of Kronprins Christian Land. East of Vandredalen, the Vandredalen thrust follows a long flat in the upper Alexandrine Bjerge Member before ramping up westwards to a flat in the upper dolostone unit of the Sjælland Fjelde Formation. The formation has been traced northwards along strike from Sæfaxi Elv as far as the western side of Hjørnegletscher, a distance of around $70 \mathrm{~km}$, and the Vandredalen thrust maintains both the same topographic level and the same stratigraphic level within the Sjælland Fjelde Formation.

The southernmost exposure of the Sjælland Fjelde Formation is close to the Inland Ice, $30 \mathrm{~km}$ west of Centrums $\varnothing$. The Alexandrine Bjerge Member is there overlain by $36 \mathrm{~m}$ of highly fossiliferous limestones that may be equivalent to the 'Opikina Limestone' of Scrutton (1975). The remainder of the interval beneath the Børglum River Formation is covered, but the likely overall thickness of the Sjælland Fjelde Formation at this locality is around $110 \mathrm{~m}$.

\section{Morris Bugt Group}

\section{Børglum River Formation}

Remarks. The Børglum River Formation comprises lithologically monotonous, burrow-mottled lime mudstones and wackestones. The formation is generally highly fossiliferous in the upper part with abundant stromatoporoids, corals, gastropods and cephalopods together with rarer brachiopods and trilobites. A distinctive $10 \mathrm{~m}$ thick dolostone horizon occurs $20 \mathrm{~m}$ below the top of the formation and constitutes a useful marker horizon in sections where the overlying Tures $\varnothing$ Formation is intensely deformed.
Substantial areas of Børglum River Formation were mapped in 1995, and the formation remains uniform throughout the mapping area. It is difficult to provide an accurate estimate of the thickness since, owing to tectonics and exposure, no sections were found in which both the upper and lower boundaries were exposed. The value of $430 \mathrm{~m}$ estimated by Smith et al. (1989) seems, however, to be a reasonably valid one.

\section{Turesø Formation}

Remarks. Previous to the 1993-1995 mapping programme, the Tures $\varnothing$ Formation was known to show a marked increase in thickness from around $150 \mathrm{~m}$ in Peary Land to over $200 \mathrm{~m}$ in northern Kronprins Christian Land (Peel 1985). This trend is maintained southwards, and a section measured $5 \mathrm{~km}$ west of Centrumsø (Fig. 6) had a thickness of $320 \mathrm{~m}$ in which subtidal burrow-mottled intervals of lime mud- and wackestone are more dominant than farther to the west in Peary Land. This produces a distinctive black and white striped appearance which is of considerable utility in identifying the formation from a distance.

The uppermost Ordovician(?) - lowermost Silurian succession in the western part of Vandredalen shows a slightly different development to the area west of Centrumsø. The tectonically deformed succession, in a major footwall ramp of the Vandredalen thrust, comprises a lower dolostone unit, a middle burrow-mottled unit and an upper dolostone unit. The lower unit is a minimum of $20 \mathrm{~m}$ thick (the base is unexposed) and comprises alternating dolostone beds and burrow-mottled limestones. It is succeeded by about $90 \mathrm{~m}$ of burrow-mottled limestones containing a diverse macrofauna, which includes brachiopods, tabulate corals, cephalopods and stromatoporoids. The $130 \mathrm{~m}$ thick upper dolostone member is made up of whiteweathering dolostone beds and interbedded dark grey limestones that give the unit a distinctive, striped appearance. The upper dolostone unit is generally poor in macrofossils, but does contain sparse stromatoporoids and brachiopods.

The southernmost occurrence of the Tures $\varnothing$ Formation is $10 \mathrm{~km}$ to the north-west of Blåsø, and the unit is here thinner (around $200 \mathrm{~m}$ ) than farther north in Kronprins Christian Land (around $300 \mathrm{~m}$ ). The base is marked by a $30 \mathrm{~m}$ thick, pale grey dolostone unit. The lowest occurrence of pentamerid brachiopods is about $140 \mathrm{~m}$ above the formation base, but it is prob- 


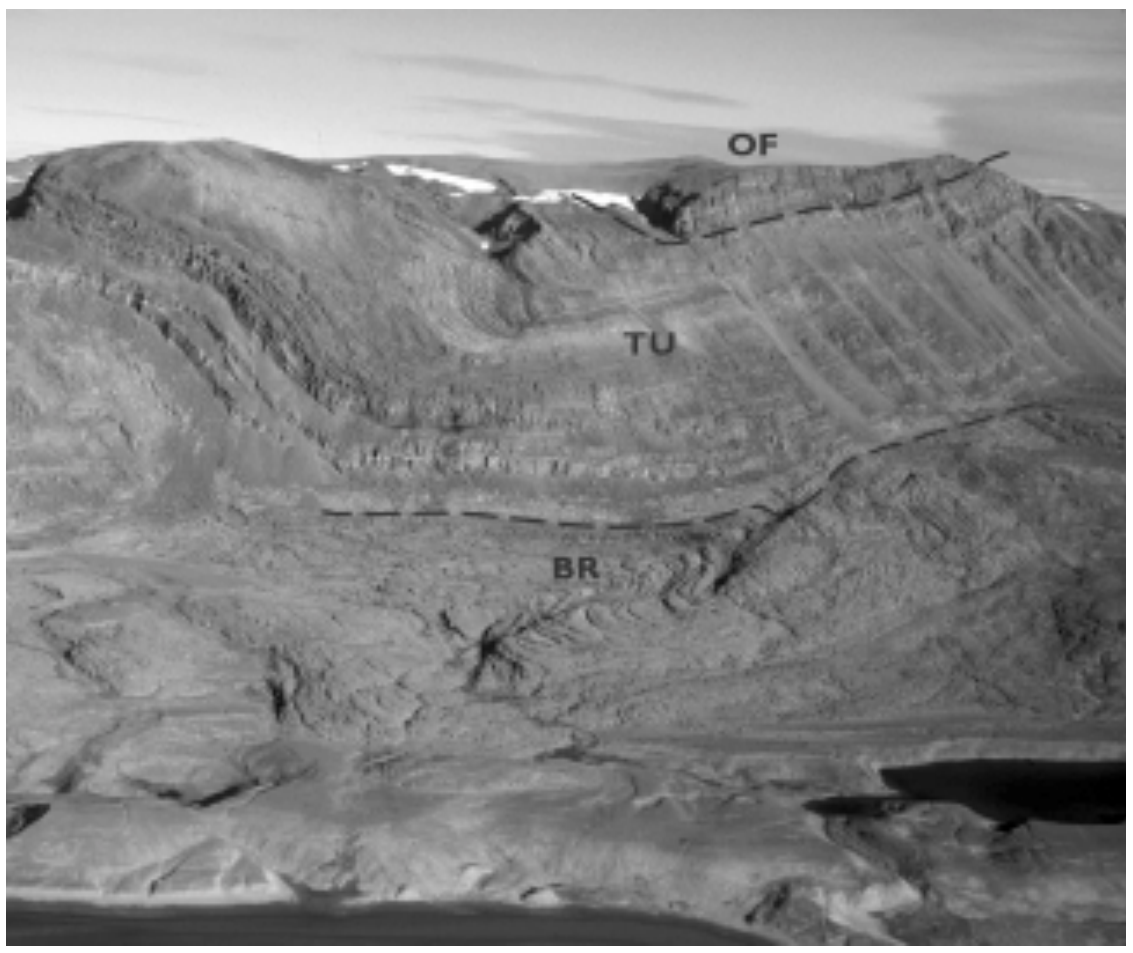

Fig. 6. Folded Middle Ordovician Silurian carbonates within the parautochthonous thrust belt, $5 \mathrm{~km}$ to the west of Centrumsø, looking northwards. BR, Børglum River Formation; TU, Tures $\varnothing$ Formation; OF, Odins Fjord Formation. Note the distinctive striped character of the Turesø Formation and the cliffforming nature of the Odins Fjord Formation. The profile is $500 \mathrm{~m}$ high.

able that the Ordovician-Silurian boundary occurs well below this level.

\section{Washington Land Group}

\section{Odins Fjord Formation}

Remarks. Although the Odins Fjord Formation is widely exposed across the area, it is rather uniformly developed, and was examined in detail only at its most southerly occurrence west of Blås $\varnothing$. The minimum thickness in this part of southern Kronprins Christian Land is $220 \mathrm{~m}$. This compares with a thickness of $200 \mathrm{~m}$ in southern Peary Land, which increases northwards to around $300 \mathrm{~m}$ approaching the shelf margin in central Peary Land (Hurst 1984).

The transition from the Tures $\varnothing$ Formation to the Odins Fjord Formation at Blås $\varnothing$ is marked by a change in weathering colour from pale grey to pale brown. At the same level, the lithology alters from dolostonedominated to limestones rich in tabulate corals and stromatoporoids. The lower $100 \mathrm{~m}$ are dominated by brown-weathering, burrow-mottled limestones, some of which are floatstones.

A very distinctive pale dolostone interval occurs 70-103 $\mathrm{m}$ above the base, and contains abundant calcite-cemented vugs, probably representing pseudo- morphed evaporitic nodules. The pale weathering, dark grey limestones are notably bituminous. This interval is at approximately the same level within the Odins Fjord Formation as the peritidal sediments of the Melville Land Member in Peary Land (Hurst 1984) and it is likely that they are broadly correlative. The interval was not initially recognised in the Centrums $\varnothing$ area, but a much thinner development at around $100 \mathrm{~m}$ above the base may be the correlative. As with the Wandel Valley Formation, the presence of intervals with shallower water lithofacies in southernmost Kronprins Christian Land suggests that a southern or eastern margin of the platform is being approached.

\section{Samuelsen Høj Formation}

Remarks. Although reefs of the Samuelsen Høj Formation had previously been documented on the northern side of Centrumsø (Fränkl 1954; Hurst 1984), they had not previously been recognised farther to the south. However, in 1994-1995 a single small reef was located within a thrust sheet that extends southwards from the western end of Centrums $\varnothing$ for around $10 \mathrm{~km}$ along the eastern side of Græselv. The small reef directly overlies stromatoporoidal biostrome facies of the Odins Fjord Formation. The reef, approximately $50 \mathrm{~m}$ in diameter and $20 \mathrm{~m}$ high, is typical of the for- 
mation, with a massive, unbedded core facies and radially dipping flank beds.

\section{Peary Land Group}

\section{Lauge Koch Land Formation}

Remarks. The southernmost occurrence of the Lauge Koch Land Formation in Kronprins Christian Land is in the parautochthonous fold-and-thrust belt immediately to the south of Centrumsø. In contrast to the typical development of the Samuelsen Høj Formation reef in this area, that of the overlying flysch is atypical. Hurst \& Surlyk (1982) assigned all of the Silurian flysch in Kronprins Christian Land to the 'Profilfjeldet Shales' of Fränkl (1954), and the unit was given member rank within the Lauge Koch Land Formation. In the type section on the west side of Vandredalen, the lower part of the Profilfjeldet Member is dominated by quartz conglomerates and sandstone turbidites. Locally, black mudstones with rare starved ripples and thin-bedded muddy siltstones are developed up to a thickness of a few metres.

In distinct contrast, the lower part of the section south of Centrums $\varnothing$ contains approximately $50 \mathrm{~m}$ of black siltstones and sandstones with interbedded carbonates overlying the Odins Fjord Formation and the Samuelsen Høj Formation reef. The black siltstones and fine- to medium-grained sandstone beds are 5$30 \mathrm{~cm}$ thick and contain planar lamination. In places a rhythmic alternation of $1 \mathrm{~cm}$ sandstone with $1-3 \mathrm{~cm}$ shaly siltstone can be seen. The interbedded carbonates are very dark grey to black, bituminous, nodular and burrow-mottled with calcite concretions; there are abundant black silty partings. The abundant macrofauna includes graptolites, cephalopods and gastropods. The interbedding of turbiditic clastic sediments with burrow-mottled carbonates is somewhat unusual, but presumably represents intermittent distal turbidite deposition in a deep subtidal setting which, during times of low clastic influx, allowed the re-establishment of carbonate deposition and a burrowing infauna.

Above the lower black shale/carbonate unit, the Lauge Koch Land Formation is more typically developed. A $25 \mathrm{~m}$ thick interval of green-weathering, very thinly bedded, shaly siltstones and sandstones is overlain by cliff-forming sandstone turbidites. The latter contain $\mathrm{T}_{\mathrm{a}-\mathrm{c}, \mathrm{e}}$ and $\mathrm{T}_{\mathrm{b}-\mathrm{e}}$ units and $4 \mathrm{~m}$ thick, massive channel fills are present. Coarsening- and thickeningupward 20-30 m cycles are also present. The thrust- truncated thickness is approximately $150 \mathrm{~m}$, well within the maximum thickness of $400 \mathrm{~m}$ cited for the member (Hurst \& Surlyk 1982).

\section{Lambert Land}

Prior to the 1993-1995 mapping programme, the Wandel Valley Formation was not known to crop out south of Kronprins Christian Land. Escher \& Jones (1994), however, pointed to the possible presence of Early Palaeozoic carbonates in westernmost Lambert Land, North-East Greenland (Fig. 2), resting unconformably upon Independence Fjord Group quartzites.

Examination of the quartzite-carbonate boundary near the Inland Ice margin in westernmost Lambert Land demonstrated that the carbonates unconformably overlie Independence Fjord Group quartzites, with a very slight angular discordance. The basal $25 \mathrm{~m}$ of the carbonates constitute a generally pale weathering unit, which is made up of current laminated dolostones with scours and some ripple lamination, together with darker wavy laminated dolostones containing ripples and drapes (Fig. 5B). Some cyclicity is evident, and the top of one cycle contains probable pseudomorphed evaporite nodules. This lower unit is overlain by highly strained, dark-weathering wavy laminated and burrow-mottled carbonates, dolomitised to greater or lesser degrees. The current laminated dolostones are absent above $25 \mathrm{~m}$.

Taking into account the lithofacies present, the unconformable relationship with the Independence Fjord Group, and the recovery of fragmentary conodonts, the Lambert Land carbonates are assigned to the Wandel Valley Formation. It is probable that the lower $25 \mathrm{~m}$ unit represents the Danmarks Fjord Member and that the overlying carbonates are part of the Amdrup Member. The thickness of the upper unit in Lambert Land is difficult to estimate due to structural complications, but it does not exceed the $200 \mathrm{~m}$ seen in the Amdrup Member in Kronprins Christian Land.

The presence of the Wandel Valley Formation resting unconformably on the Independence Fjord Group demonstrates that the progressive overstep of the Early Ordovician from west to east across North Greenland (Peel \& Smith 1988, fig. 6) continues into Kronprins Christian Land, where it rests on the Kap Holbæk Formation in the west and the Fyns Sø Formation in the east, and southwards to Lambert Land (Fig. 7). The pattern is suggestive of a strong N-S component in addition to the well-documented west to east over- 


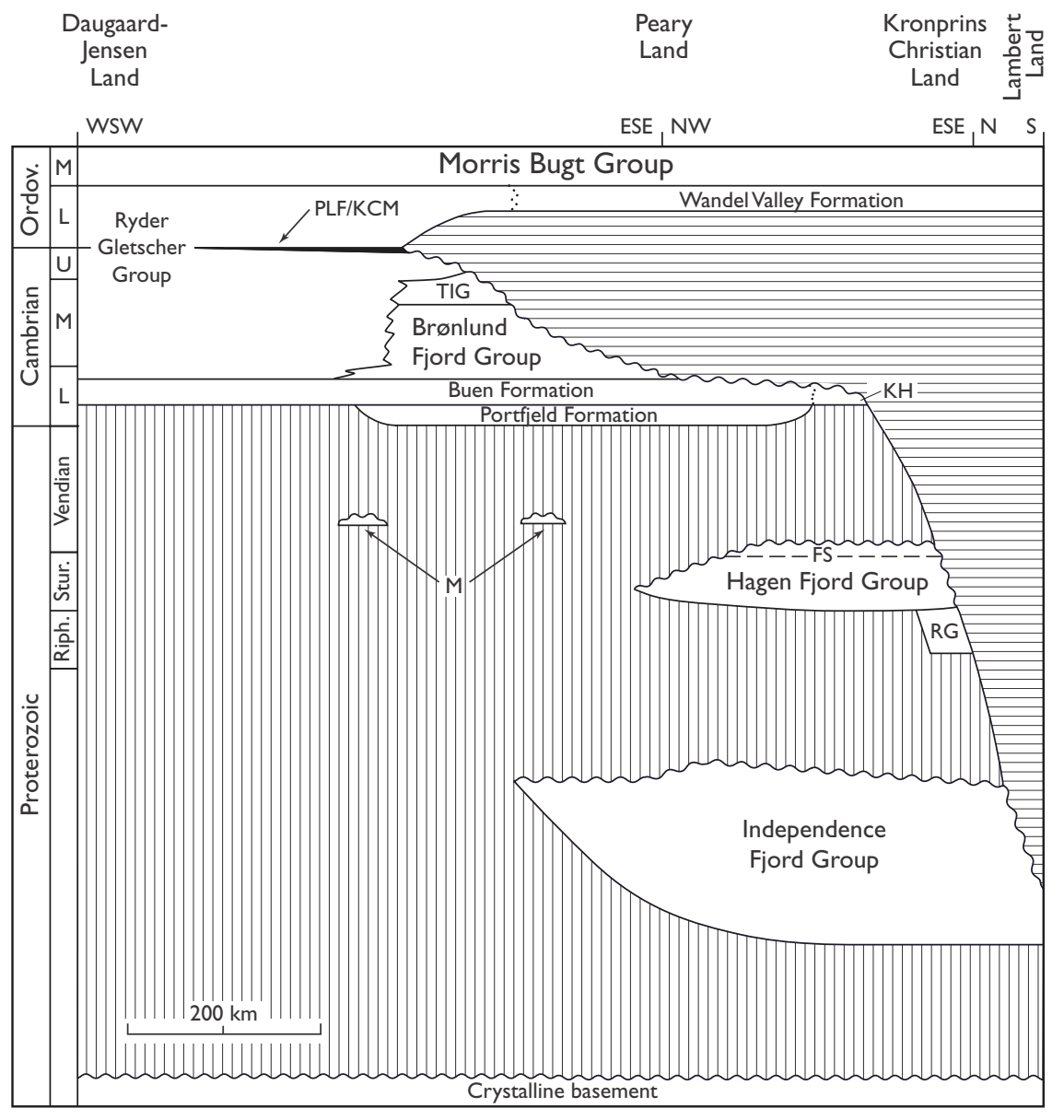

Fig. 7. Proterozoic - Middle Ordovician stratigraphic relationships on the platform area of North and North-East Greenland, showing the extent and magnitude of the sub-Wandel Valley unconformity. Maximum uplift and associated erosion was in Lambert Land, at the extreme right hand side of the diagram. The locations of Daugaard-Jensen Land and Peary Land are indicated on the inset map of Greenland in Fig. 2. FS, Fyns $S \varnothing$ Formation (Hagen Fjord Group); KH, Kap Holbæk Formation; M, glacial sediments of the Morænes $\varnothing$ Formation; PLF/KCM, quartz arenite sandstone sheet assigned to the Permin Land Formation and the Kap Coppinger Member; RG, Rivieradal Group (see Smith et al. 2004, this volume); TIG, Tavsens Iskappe Group. Modified from Smith (2000).

step, and perhaps indicates that maximum pre-Wandel Valley Formation uplift was farther to the south than hitherto anticipated. The depositional environments are broadly comparable with the development to the north, but the burrow-mottled upper unit in Lambert Land seems to be of slightly shallower water origin than the Amdrup Member, suggesting proximity to a southern and/or eastern margin to the Franklinian platform in Lambert Land.

\section{Dronning Louise Land}

The extensive nunatak region of Dronning Louise Land (Fig. 1) was first documented geologically during the 1952-1954 British North Greenland expedition (Peacock 1956, 1958). The region was not re-investigated in detail until the systematic mapping programme conducted by GGU in 1989-1990 (Friderichsen et al. 1990; Holdsworth \& Strachan 1991; Strachan et al. 1994). Dronning Louise Land is divided by a N-S-trending imbricate zone into an autochthonous foreland area to the west, and parautochthonous to allochthonous Palaeoproterozoic gneiss complexes with interbanded metasedimentary rocks to the east, transported westwards as thrust sheets. The foreland area comprises crystalline basement orthogneisses overlain by sequences of sedimentary rocks assigned to the 'Trekant' and 'Zebra series'. The older 'Trekant series' and underlying basement gneisses are intruded by dolerite dykes, and are overlain unconformably by the 'Zebra series'. The 'Zebra series' is also present in the imbricate zone where it overlies pale grey-green sandstones that are intruded by metadolerites.

\section{Facing page:}

Fig. 8. Geological map of North-East Greenland 71050'$74^{\circ} 30^{\prime} \mathrm{N}$, showing location of the Eleonore $\mathrm{S} \varnothing$, Målebjerg, and Charcot Land windows. The legend depicts the units contained in the two thrust sheets and Franz Joseph allochthon, which overlie the windows. AEL, Arnold Escher Land; ES, Eleonore $\$ \varnothing$; G, Gemmedal; HB, Albert Heim Bjerge; KFJF, Kejser Franz Joseph Fjord; M, Målebjerg; ML, J.L. Mowinckel Land; ON, C.H. Ostenfeldt Nunatak; S, Slottet. 


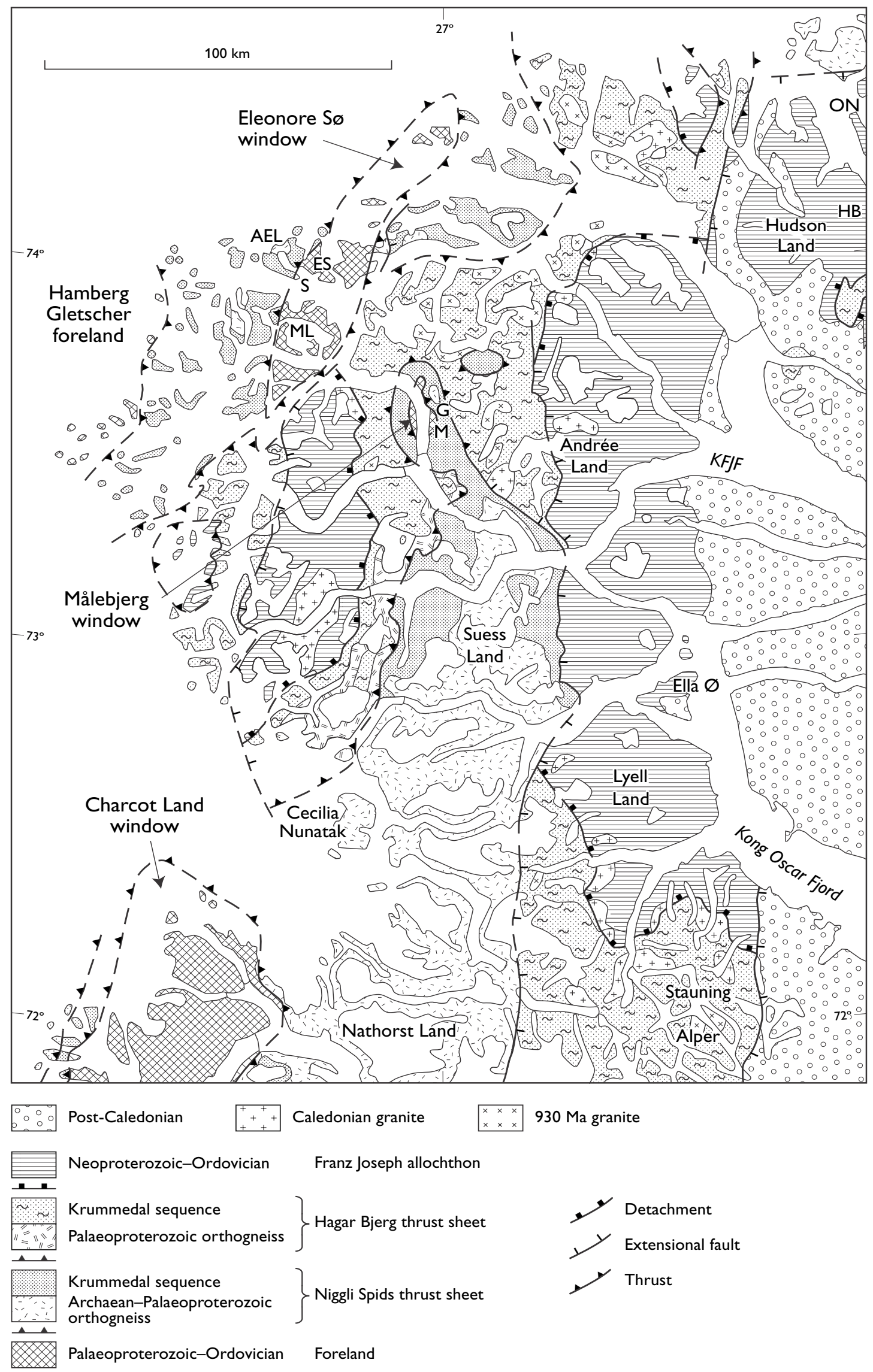


In the foreland of north-west Dronning Louise Land, the 'Zebra series' comprises 3-10 m of basal pebble conglomerates, overlain by $10-15 \mathrm{~m}$ of purple-white striped quartzites. These pass upwards into yellowwhite medium- to coarse-grained quartzites $(5-30 \mathrm{~m})$ and interbanded magnetite sandstones, siltstones and mudstones (10 m; Friderichsen et al. 1990). These clastic rocks are overlain by around $10 \mathrm{~m}$ of fine-grained grey-black limestones. Deep Skolithos burrows are found in situ in the quartzites demonstrating, as with the Kap Holbæk Formation, that the 'Zebra series' is no older than Cambrian. The quartzites are thus correlative with the Kap Holbæk Formation of Kronprins Christian Land, the Slottet Formation of the Eleonore Sø and Målebjerg windows (see below), and the Kløftelv Formation (Kong Oscar Fjord Group - see below) of the Franz Joseph allochthon.

A similar succession is present within the 'Zebra series' of the imbricate thrust zone where, in central Dronning Louise Land, Friderichsen et al. (1990) recorded $2 \mathrm{~m}$ of pale green sandstones with thin lensoid pebble beds up to $20 \mathrm{~cm}$ thick at the base, overlain by $45 \mathrm{~m}$ of white to rusty weathering medium-grained quartzites with abundant tabular cross-bedding. These beds are overlain by a heterogeneous $50 \mathrm{~m}$ package of interbedded grey-green siltstone, dark mudstone, thin quartzites, yellow sandstones and limestones. The base of this latter unit contains ichnofossils assigned to Cruziana sp. (Strachan et al. 1994), which indicate a maximum age of Atdabanian (mid-Early Cambrian; Crimes 1992b). The quartzites are overlain by about $120 \mathrm{~m}$ of grey dolomitic limestones - a stratigraphic signature that is very similar to the successions in the Eleonore Sø and Målebjerg windows (see below). The precise age of the dolomitic limestones at the top of the 'Zebra series' in both the foreland and imbricate zone is uncertain, but they must be of Cambrian-Ordovician age.

\section{Nunatak region $71^{\circ} 50^{\prime} \mathrm{N}-7^{\circ} 30^{\prime} \mathrm{N}$}

The presence of in situ Lower Palaeozoic sediments in the western nunatak region of the southern part of the East Greenland Caledonides (Fig. 8) had not been demonstrated prior to the 1997-1998 Survey mapping programme. However, several clues had been noted, namely the presence of erratic carbonate blocks containing Early Ordovician conodonts on Cecilia Nunatak $\left(72^{\circ} 30^{\prime} \mathrm{N}\right.$; J.S. Peel in Higgins et al. 1981), and the abundant occurrence of quartz arenite blocks contain- ing Skolithos throughout the Caledonides (see e.g. Haller 1971, fig. 48). Two tectonic windows through thrust sheets (Leslie \& Higgins 1998, 1999) discovered in 1997 revealed the presence of Vendian tillites, Cambrian sandstones and Cambrian-Ordovician carbonates in the footwall immediately underlying the bordering thrusts; these distinctive successions record the effects of Caledonian deformation, and have been interpreted as representing autochthonous to parautochthonous Caledonian foreland (Higgins et al. 2001a). While the strain levels in these units are high, sufficient sedimentary detail can be observed to allow confident interpretation and correlation.

\section{Slottet Formation}

new formation

History. The 'Slottet Quartzite' was first described by Katz (1952) from the Eleonore Sø region $\left(74^{\circ} \mathrm{N}\right)$, and was included within a group of rocks that was correlated with the upper part of what is now the Nathorst Land Group (lower Eleonore Bay Supergroup). Subsequently, Haller (1971), following a suggestion of Wenk (1961), assigned the quartz-arenite unit to his 'Basal Series' of the Eleonore Bay Supergroup. This complex of rocks included a wide variety of lithologies, and it is now clear that a wide range of ages is also represented (Leslie \& Higgins 1998, 1999). As part of the systematic re-mapping programme of 1997-1998, the Eleonore $S \varnothing$ region was revisited, and it was recognised that the rock units were located within a major

\section{Facing page:}

Fig. 9. A: Quartzites of the Slottet Formation (SF) a few hundred metres north of the type section, overlying a clastic unit that includes diamictites (VT). The light coloured quartzites of the Slottet Formation are clearly visible in the cliffs of Målebjerg in the background. A few metres of carbonate (not visible) represent the Målebjerg Formation, with the Niggli Spids thrust (NST) marking the upper limit of the unit. View looking south to Målebjerg (1873 m high), the summit of which is about $1500 \mathrm{~m}$ above the ice-dammed lake and glacier. B: Skolithos burrows in quartzite from the Slottet Formation of the Eleonore Sø window. Distortion of the upper part of the burrows, along bedding planes, is a consequence of westward displacement of the overriding Caledonian thrust sheets. C: Highly strained, parallel laminated dolostones and burrow-mottled limestones of the Målebjerg Formation at the type section, to the north of Målebjerg, in the Målebjerg window. 


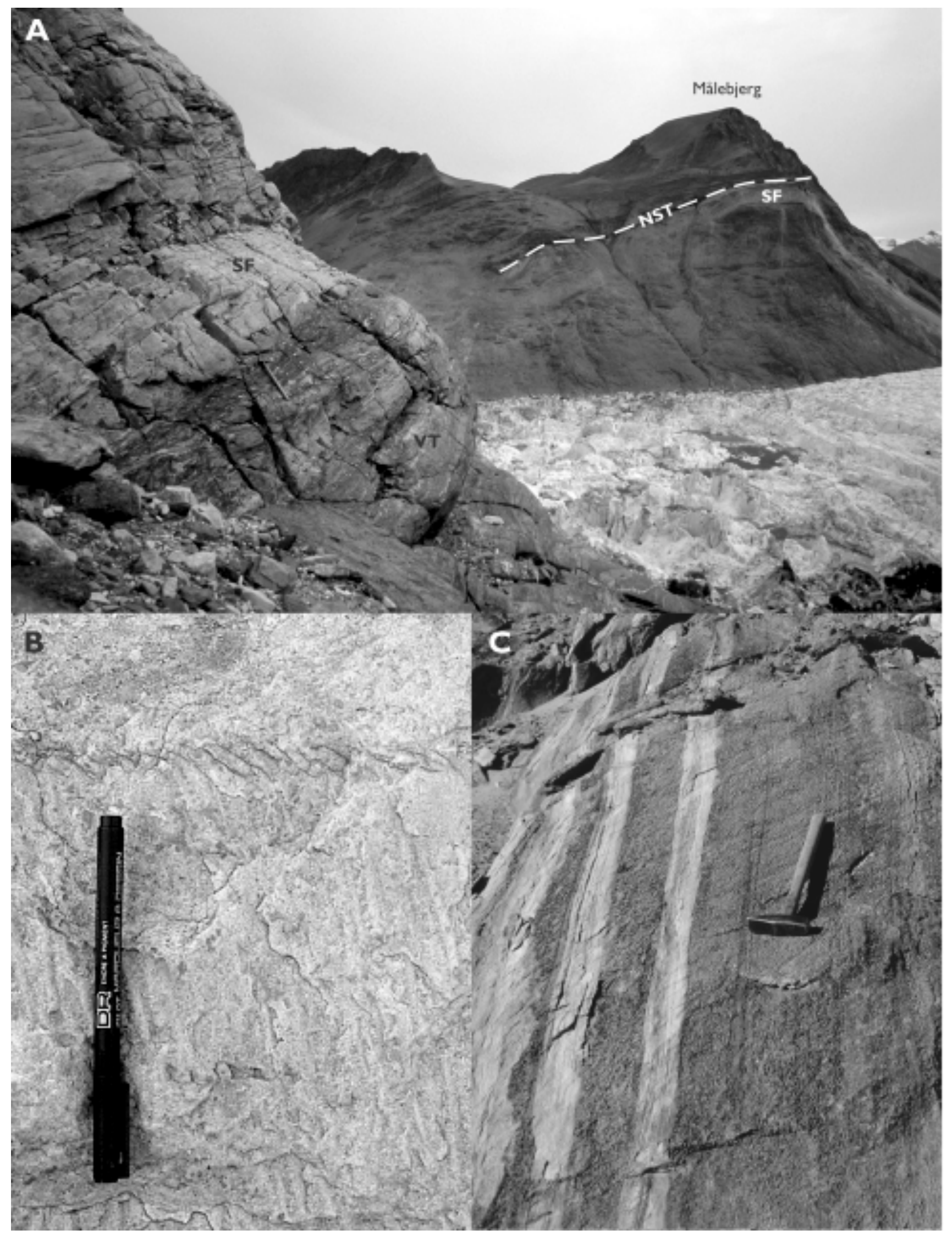


window through a Caledonian thrust sheet. When the effects of Caledonian deformation were restored, it became clear that Haller's (1971) supposed 'Basal Series' in this region is a complex of volcanic and sedimentary rocks deposited in a rift setting and unconformably overlain by the Slottet Formation (Leslie \& Higgins 1998). The older group of rocks was informally termed the 'Eleonore Sø complex', while the discovery of Skolithos burrows in the younger 'Slottet quartzite' indicated the Cambrian age of the unit (Leslie \& Higgins 1998; Smith \& Robertson 1999b).

Further outcrops of the 'Slottet quartzite' were located $70 \mathrm{~km}$ east of the Eleonore $\$ \varnothing$ region at the foot of Målebjerg, in another smaller tectonic window through a Caledonian thrust, now known as the Målebjerg window. These outcrops were originally mapped by Haller (1953), and their resemblance to the 'Slottet quartzite' was pointed out by Haller (1971) who also placed them in his 'Basal Series' of the Eleonore Bay Supergroup.

Name. The formation is named after the promontory of Slottet ('the castle') to the south of Eleonore Sø, where the unit crops out spectacularly and was first described by Katz (1952).

Type section. The north side of the ice-dammed lake in Gemmedal, north of Målebjerg (Fig. 9A).

Thickness. At the type section, the formation is $143 \mathrm{~m}$ thick (Fig. 10). In the vicinity of Slottet, photogrammetric calculations suggest that the unit is considerably thicker, of the order of $350 \mathrm{~m}$ (see photograph on front cover of this volume) although this is much less than the $>1000 \mathrm{~m}$ estimate derived from Katz's observations that was quoted by Haller (1971).

Lithology. In the type section north of Målebjerg (Figs 9A, 10), the lower $10 \mathrm{~m}$ comprise structureless or planar laminated, fine- to coarse-grained quartz arenites in $10-30 \mathrm{~cm}$ beds. From $10-36 \mathrm{~m}$, the maximum grain size diminishes, and fine- to medium-grained sandstones occur in $0.2-1.6 \mathrm{~m}$ beds. The quartz arenites are parallel laminated and cross-bedded, the latter sometimes being of very large scale, with sets up to $1.6 \mathrm{~m}$. Some beds are lenticular at outcrop scale, and shaly interbeds are sometimes present. Above $36 \mathrm{~m}$, the fine-grained quartz arenites are in beds of $0.3-$ $1.5 \mathrm{~m}$ thickness, and are either structureless or crossbedded with sets up to $1 \mathrm{~m}$ and very low angle foresets. The beds are mainly tabular, but some are seen to

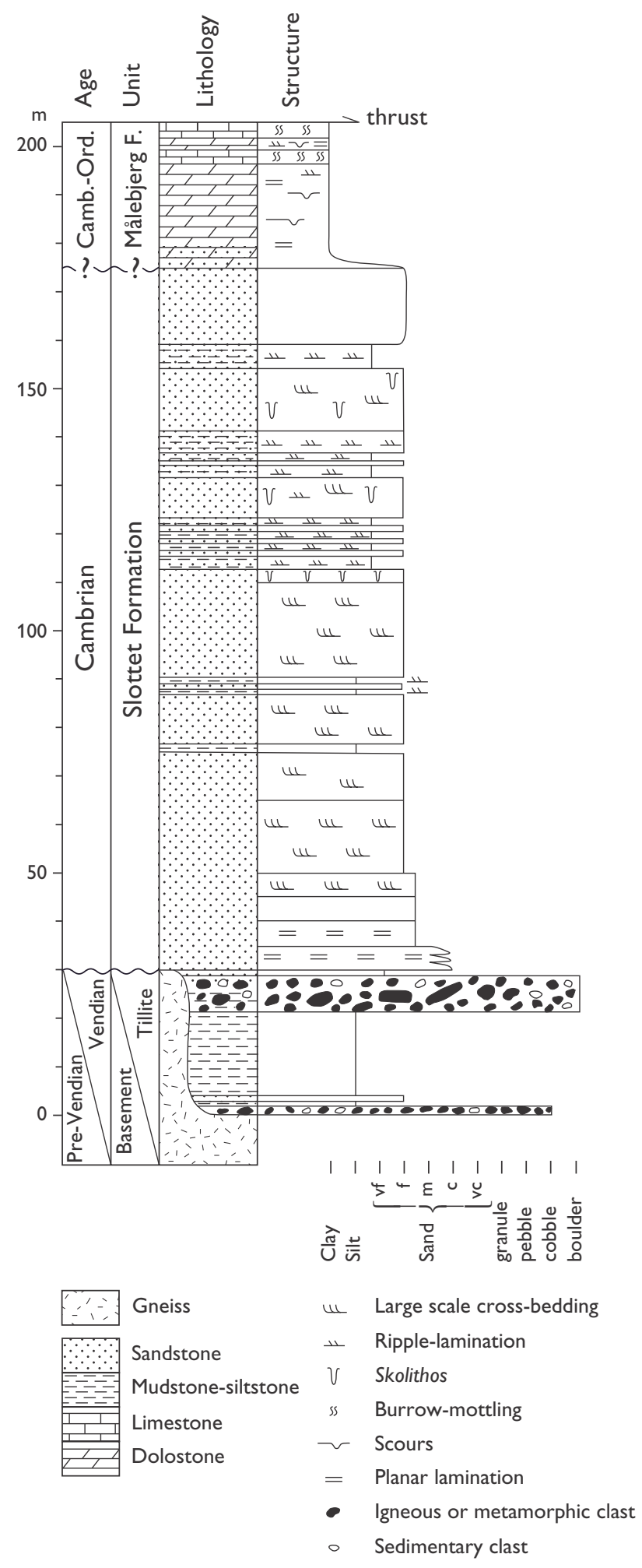

Fig. 10. Composite log of the Slottet and Målebjerg Formations at the type locality in the Målebjerg window. The lenticular clastic succession beneath the Slottet Formation, with two diamictite levels, occupies a depression in the gneissic basement, and is interpreted as a Vendian tillite. 
wedge out at outcrop scale. Interbeds of thin sandstones and sandy shales up to $0.4 \mathrm{~m}$ thick occur. Current directions determined from foreset orientation are predominantly towards the south-east.

At $79 \mathrm{~m}$, there is a conspicuous change from golden brown-weathering quartz arenites to a rusty weathering alternation of interbedded quartz arenites and sandy shales. This unit is $50 \mathrm{~m}$ thick (79-129 m) although above $112 \mathrm{~m}$ the mud content falls off. The quartz arenites are in beds of $<15-60 \mathrm{~cm}$ and are largely structureless, although hints of cross-bedding do occur. The sandy shales comprise mudstones (now slaty) with lenticular sand bodies up to a few centimetres thick and traces of ripple lamination. In some places, mud drapes were observed on foreset laminae. The formation is capped by a $14 \mathrm{~m}$ thick massive quartz arenite that is structureless and virtually unbedded.

Boundaries. North of Målebjerg, in the type section on the north side of the ice-dammed lake in Gemmedal (Fig. 8), the Slottet Formation lies unconformably on gneisses of probable Palaeoproterozoic age. However, a few hundred metres farther north the gneisses are overlain by a lenticular tillite unit with a maximum thickness of $31 \mathrm{~m}$ (Figs 9A, 10). The unit contains two beds of diamictite separated and overlain by platy quartzites, phyllites and semi-pelites. This unit can be seen to gradually wedge out southwards, and occupies a hollow on a peneplaned surface of basement gneisses. The lower part of the lower diamictite bed $(1.4 \mathrm{~m})$ comprises clast-supported pebbles and cobbles resting on sheared granitic gneiss, but within 30 $\mathrm{cm}$ there is a gradation up into matrix-supported diamictites. The matrix is composed of fine sand which in places is micaceous and phyllitic. The upper diamictite bed is up to $7.6 \mathrm{~m}$ thick, but thickens and thins markedly along strike. The clasts are dominated by fine- to coarse-grained granitic lithologies but also include metasandstones and carbonates, with the latter up to $6 \times 1.5 \times 1 \mathrm{~m}$ in size. The unit is considered to be of Varanger age and is disconformably overlain by the Slottet Formation.

Distribution. The Slottet Formation occurs around the margins of the Eleonore $\mathrm{S} \varnothing$ and Målebjerg tectonic windows. Within the Eleonore $\$ \varnothing$ window, the formation is present in J.L. Mowinckel Land, Arnold Escher Land and around Eleonore Sø itself, and in the Målebjerg area it crops out on either side of the N-Strending glacier that bisects the window.
Fauna and age. The Slottet Quartzite is characterised by the presence of Skolithos burrows that attain lengths of several tens of centimetres (Fig. 9B). The first unequivocal appearance in the type section is at the base of the rusty weathering unit ( $79 \mathrm{~m})$, but more equivocal examples are present as low as $45 \mathrm{~m}$. As noted in the discussion of the Kap Holbæk Formation, the presence of deep Skolithos indicates an age for the unit that is no older than Tommotian (mid-Early Cambrian).

\section{Målebjerg Formation}

new formation

History. Katz (1952) recognised and mapped a carbonate unit above his 'Slottet quartzite' in the eastern Eleonore $S \varnothing$ region, but considered it to represent mylonitised Eleonore Bay Supergroup. In the 19971998 field seasons it was recognised that the carbonate unit, although highly strained, conformably overlies the Slottet Formation and lies in the footwall of the thrust that bounds the Eleonore $\$ \varnothing$ and Målebjerg windows (Leslie \& Higgins 1998; Smith \& Robertson 1999b).

Name. Named after the mountain Målebjerg, which lies immediately to the south of the type section.

Type section. The type section of the Målebjerg Formation is a continuation of the Slottet Formation type section, on the northern side of the ice-dammed lake in Gemmedal, north of Målebjerg (Fig. 10). A better exposed, but less accessible, reference section is present on a nunatak $\left(73^{\circ} 41^{\prime} \mathrm{N}, 28^{\circ} 40^{\prime} \mathrm{W}\right)$ south of J.L. Mowinckel Land, within the Eleonore Sø window.

Thickness. In the type section (Fig. 10), $32 \mathrm{~m}$ of sediment are preserved beneath the thrust that terminates the section. In the reference section, the formation is $45 \mathrm{~m}$ thick, and a similar thickness is present wherever it crops out within the Eleonore $\$ \varnothing$ window.

Lithology. In both of the measured sections, the Slottet Formation is overlain by $1.5 \mathrm{~m}$ of sandy dolostones. In the type section the next $20 \mathrm{~m}$ are poorly exposed, but dark grey weathering medium grey dolostones and pale grey weathering pale grey dolostones with current lamination were observed. The uppermost 9 $\mathrm{m}$ comprise buff-weathering, parallel laminated dolostones (Fig. 10) interbedded with dark grey limestones 
with buff dolomite burrow fills. In places these can be seen to be shallowing-upward, subtidal burrowmottled limestone - peritidal dolostone cycles similar to those that commonly occur elsewhere in the Laurentian Cambrian-Ordovician.

In the reference section in J.L. Mowinckel Land, the basal sandy dolostones become progressively less sandy upwards; parallel lamination and ripple lamination with dolomitic mud drapes are present. This unit is overlain by $3.5 \mathrm{~m}$ of dolostones in which $2-3$ $\mathrm{cm}$ beds of fine-grained dolostone alternate with 0.5 $\mathrm{cm}$ beds of coarser, sand-grade, dolomite. The latter are parallel laminated and low amplitude ripples are also developed. From 5-20 m, massive buff-weathering pale grey dolostones occur in beds up to $2.5 \mathrm{~m}$ thick. For the most part these beds are structureless but traces of burrow-mottling are present in places, as are fenestral, laminated dolostones and current lamination. More thinly bedded dolostones make up the interval from $20-40 \mathrm{~m}$; these are predominantly structureless or current laminated, and extensively veined with quartz and carbonate. The uppermost $5 \mathrm{~m} \mathrm{com-}$ prise dark, burrow-mottled limestones with buff burrow fills that become increasingly strained and mylonitised towards the thrust that terminates the section.

Boundaries. In both sections, the basal sandy dolostones overlie the Slottet Formation with no angular discordance and the succession is truncated by the thrust that bounds the tectonic windows.

Distribution. As with the Slottet Formation, the carbonate unit is restricted to the margins of the Eleonore Sø and Målebjerg windows. However, because it is markedly thinner and less resistant to weathering it crops out less frequently.

Fauna and age. There is, to date, no fauna recorded from the Målebjerg Formation, although its tectonic context and the presence of bioturbation in the form of burrow-mottling, together with its conformable boundary with the underlying Slottet Formation, suggest a Cambrian-Ordovician age.

\section{Fjord region $71^{\circ} 36^{\prime}-74^{\circ} 17^{\prime} \mathrm{N}$}

The presence of Cambrian-Ordovician sediments within the outer fjord region of North-East Greenland $\left(71^{\circ} 36^{\prime}-74^{\circ} 17^{\prime} \mathrm{N}\right.$; Fig. 8) has been known since the early work of Lauge Koch and Christian Poulsen. Their good exposure and relative ease of access has resulted in more research than areas to the north (for reviews see Cowie \& Adams 1957; Henriksen \& Higgins 1976; Smith \& Bjerreskov 1994; Stouge et al. 2001). The tectonic setting has, however, remained rather more enigmatic since, although clearly incorporated within the Caledonian orogen, the units are relatively undeformed. Mapping of the underlying Eleonore Bay Supergroup in 1997-1998 has clarified this relationship, and it is now apparent that the Lower Palaeozoic rocks of the fjord region are part of the highest level thrust sheet in this sector of the orogen, and have been transported several hundreds of kilometres from the eastsouth-east (Smith \& Robertson 1999a, b; Higgins \& Leslie 2000; Higgins et al. 2004a) before involvement in syn- to post-orogenic collapse (Hartz \& Andresen 1995; Andresen et al. 1998).

The Cambrian-Ordovician formations are here incorporated within the newly erected Kong Oscar Fjord Group (Fig. 11).

\section{Kong Oscar Fjord Group}

new group

History. Recorded observations of the Lower Palaeozoic rocks of the fjord region extend back to Karl Koldewey's expedition of 1869-1870 when Palaeozoic sediments similar to the 'Hekla Hoek Formation' of Spitsbergen were documented (Toula \& Lenz 1874). Palaeontological confirmation of this stratigraphical determination came from A.G. Nathorst's expedition of 1899, which re-visited Kejser Franz Joseph Fjord and recovered 'Silurian' and Devonian fossils (Nathorst 1901). The Lower Palaeozoic was further examined by the Cambridge expedition of 1926 under the leadership of J.M. Wordie (Wordie 1927), and in the same year Lauge Koch led the first of a series of expeditions that were to make a major impact on the understanding of East Greenland Caledonian geology. The latter expeditions continued until 1958 with breaks only for the war years. Towards the end of this programme, P.J. Adams and J.W. Cowie carried out a detailed investigation of the Lower Palaeozoic, and the ensuing monograph (Cowie \& Adams 1957) remains a key publication. K. Swett and co-workers carried out some sedimentological work in the early 1970s, including comparisons with coeval successions in north-east Spitsbergen and north-west Scotland (e.g. 


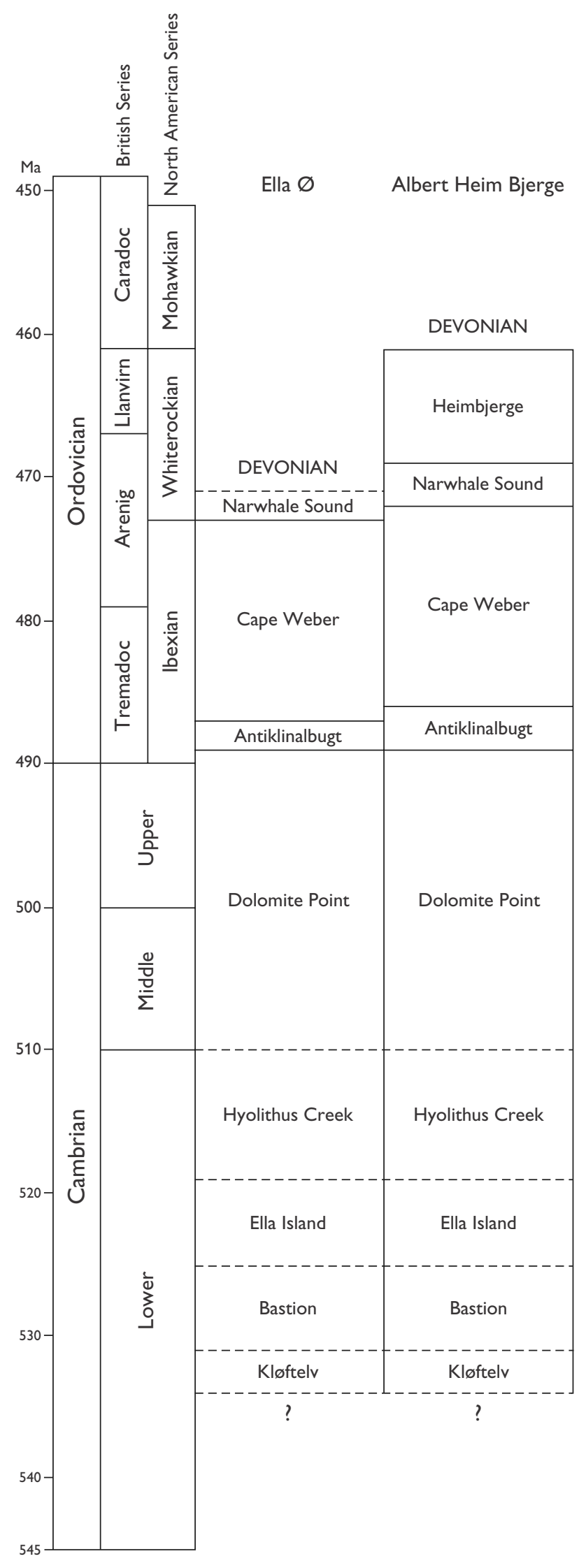

Swett \& Smit 1972). Extensive logging and sample collecting for conodont work was carried out by P. Frykman in 1977, and by M.P. Smith and J.S. Peel in 1988. This has resulted inter alia in a refinement of biostratigraphical constraints, particularly in the Late Cambrian - Ordovician part of the group (Smith 1985, 1991; Smith \& Bjerreskov 1994; Huselbee 1998). Additional field work has been carried out in the succession by Stouge et al. (2001, 2002), and documentation of Early Cambrian small shelly faunas was undertaken, with subsequent biostratigraphic refinements, by Skovsted (2003).

Name. Named after Kong Oscar Fjord, at the head of which lies the island of Ella $\varnothing$ with the most easily accessible and most studied outcrops of the group (Fig. 12A).

Type area. In view of the above, the most suitable type area is Ella $\varnothing$. Important reference areas, which contain the only complete sections through the two youngest formations, are present in the north of the outcrop belt at Albert Heim Bjerge and C.H. Ostenfeld Nunatak (Fig. 8; Cowie \& Adams 1957; Frykman 1979; Hambrey et al. 1989; Smith 1991; Smith \& Bjerreskov 1994; Stouge et al. 2002).

Thickness. On Ella $\varnothing$, the group is $2625 \mathrm{~m}$ thick (Cowie \& Adams 1957; Smith \& Bjerreskov 1994) including a revised thickness of $1161 \mathrm{~m}$ for the Cape Weber Formation (Smith 1991). The upper part of the group thickens northwards (and perhaps also eastwards), and Frykman (1979) recorded an apparently unfaulted thickness of $1750 \mathrm{~m}$ for the Cape Weber Formation on C.H. Ostenfeld Nunatak. In addition, Frykman (1979) estimated a thickness of $1200 \mathrm{~m}$ for the Heimbjerge Formation on C.H. Ostenfeld Nunatak, rather than the maximum $320 \mathrm{~m}$ recorded beneath Devonian red beds on Albert Heim Bjerge (Cowie \& Adams 1957). The Kong Oscar Fjord Group in the northernmost part of

Fig. 11. Correlation chart of units within the Kong Oscar Fjord Group on Ella $\varnothing$ and Albert Heim Bjerge, showing component formations of Upper Cambrian - Ordovician age. The age of the base of the Kløftelv Formation is uncertain. The absolute ages of chronostratigraphic boundaries are compiled from Tucker \& McKerrow (1995), Cooper (1999) and Encarnacíon et al. (1999). Stratigraphic dates for the unit boundaries are based on Henriksen \& Higgins (1976), Pickerill \& Peel (1990), Smith \& Bjerreskov (1994) and Huselbee (1998). 


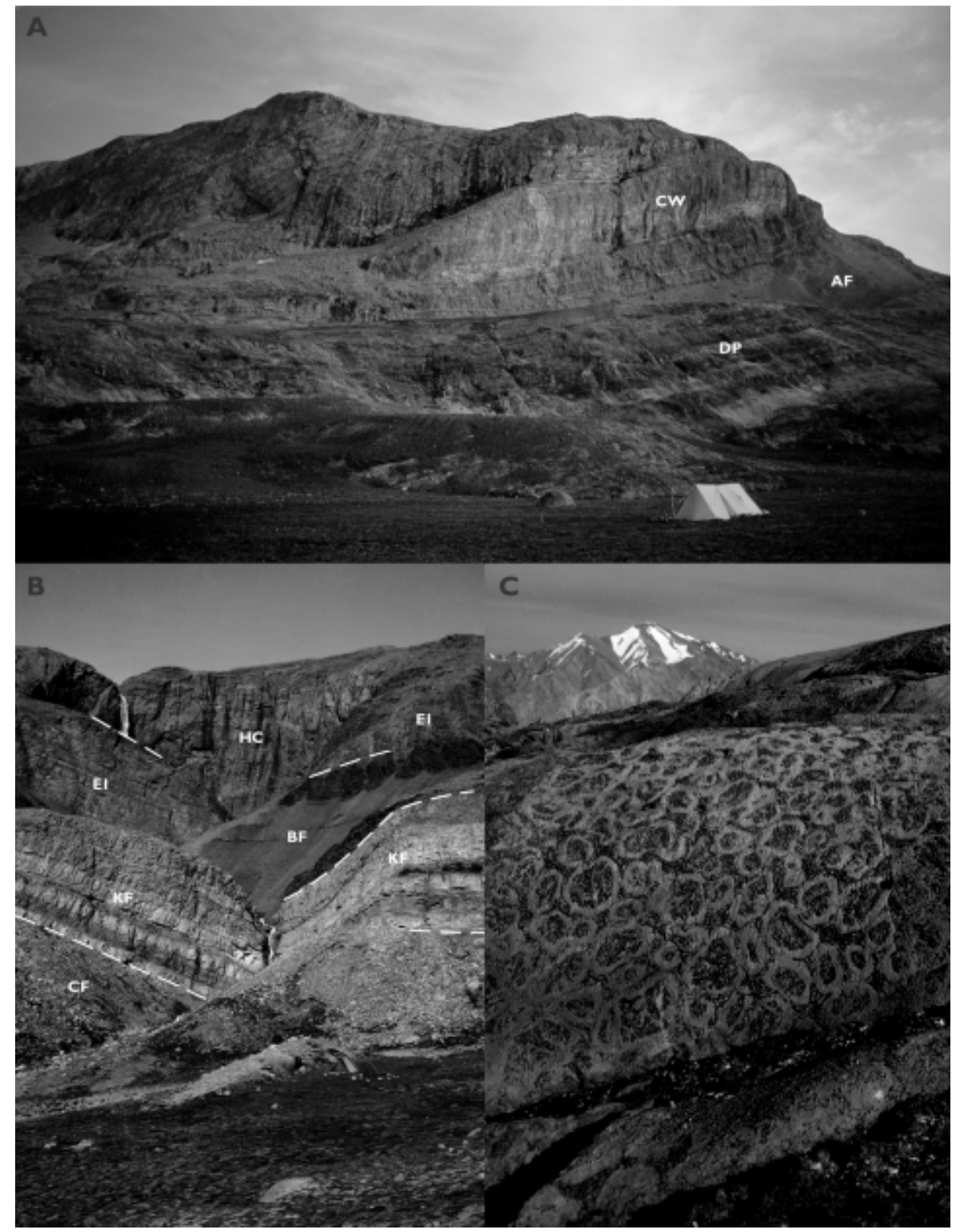


the outcrop belt is thus likely to be around $4500 \mathrm{~m}$ thick, its maximum within the region.

Dominant lithology. The lower part of the group (Kløftelv Formation and Bastion Formation) is dominated by quartz arenites that fine upwards into glauconitic sandstones, and sandy micaceous and ferruginous shales. Clastic supply wanes in the upper Bastion Formation, and the remainder of the group is carbonate-dominated. The Ella Island Formation is limestone-dominated, but the succeeding two units, the Hyolithus Creek Formation and Dolomite Point Formation, are dolostone-dominated.

The Ordovician units comprise an alternation of thick, pale grey, homogeneous subtidal limestones (Cape Weber Formation and Heimbjerge Formation), with more thinly bedded units in which subtidal or subtidal-peritidal shallowing-upwards sequences are developed on the scale of $1-5 \mathrm{~m}$ (Antiklinalbugt Formation and Narwhale Sound Formation). Significant developments of thrombolitic-stromatolitic reefs are present in the basal part of the Antiklinalbugt Formation on Ella $\varnothing$ (Fig. 12C) and the lower $100 \mathrm{~m}$ of the Cape Weber Formation on Albert Heim Bjerge and C.H. Ostenfeld Nunatak (Hambrey et al. 1989; Stouge et al. 2001).

Boundaries. The Kong Oscar Fjord Group overlies the Tillite Group. At outcrop scale, the boundary appears to be sharp but conformable. However, northwards along strike the uppermost unit of the Tillite Group, the Spiral Creek Formation (maximum thickness 55 m) wedges out and the Kløftelv Formation rests on the underlying Canyon Formation (Fig. 12B; Hambrey \& Spencer 1987; Hambrey et al. 1989). It is thus prob-

\section{Facing page:}

Fig. 12. A: The Kong Oscar Fjord Group on Ella $\varnothing$, showing Upper Cambrian - Ordovician formations. AF, Antiklinalbugt Formation; CW, Cape Weber Formation; DP, Dolomite Point Formation. The highest summit visible is $500 \mathrm{~m}$ above the tent in the foreground. B: The Kong Oscar Fjord Group on Albert Heim Bjerge, showing Lower Cambrian formations, with the lowermost Kløftelv Formation (KF) unconformably overlying the Neoproterozoic Canyon Formation (CF) of the Tillite Group. BF, Bastion Formation; EI, Ella Island Formation; HC, Hyolithus Creek Formation. Tent at lower right for scale. The height of the profile is $c .600 \mathrm{~m}$. C: Thromboliticstromatolitic reefs in the basal part of the Antiklinalbugt Formation on Ella $\varnothing$. The oval to rounded thrombolites are about $25 \mathrm{~cm}$ in diameter. able that a regional hiatus and/or low angle unconformity is present at the base of the Kløftelv Formation.

Stouge et al. (2001, 2002) inferred the presence of a significant disconformity or condensed interval at the Antiklinalbugt Formation - Cape Weber Formation boundary. The Antilklinalbugt Formation contains early Ibexian macro- and microfaunas, and a cephalopod identified as ?Cyptendoceras sp. indet. recovered from the basal beds of the Cape Weber Formation was considered to be of late Ibexian age. Together with the absence of a middle Ibexian macrofauna, this evidence was used to invoke the presence of a disconformity or condensed interval spanning the middle Ibexian. However, closely spaced conodont samples throughout the interval from the upper Dolomite Creek Formation to the top of the Cape Weber Formation (Smith 1985, 1991; Huselbee 1998) demonstrate that there is a complete succession, and that there is no significant disconformity or condensed interval present.

The upper part of the group is cut by the Caledonian erosion surface, and is overlain by Devonian molasse of the Kap Kolthoff Group. On Ella $\varnothing$, the erosion level is within the middle part of the Narwhale Sound Formation, and on Albert Heim Bjerge it cuts through the lower part of the Heimbjerge Formation, whereas on C.H. Ostenfeld Nunatak a much thicker section in the latter unit is preserved. Complete sections through the Narwhale Sound Formation and the overlying Heimbjerge Formation are thus present only in the northern part of the outcrop belt.

Distribution. The group is present in a narrow belt that extends from Canning Land $\left(71^{\circ} 36^{\prime} \mathrm{N}\right)$ through the fjord region to C.H. Ostenfeld Nunatak $\left(74^{\circ} 17^{\prime} \mathrm{N}\right)$, and is confined to the Franz Joseph allochthon. The main outcrop forms part of the Neoproterozoic-Ordovician division shown in Fig. 8; the detached outcrops on Canning Land lie $90 \mathrm{~km}$ east-south-east of the south-east corner of Fig. 8.

Geological age. Early Cambrian - Upper Whiterockian (Middle Ordovician - upper Llanvirn sensu Fortey et al. 1995).

Subdivision. The Kong Oscar Fjord Group contains nine formations: Kløftelv Formation, Bastion Formation, Ella Island Formation, Hyolithus Creek Formation, Dolomite Point Formation, Antiklinalbugt Formation, Cape Weber Formation, Narwhale Sound For- 
mation and the Heimbjerge Formation (Fig. 11). The Cambrian-Ordovician boundary occurs within the uppermost part of the Dolomite Point Formation (Miller \& Kurtz 1979; Huselbee 1998).

The Lower Palaeozoic units of the East Greenland foreland, observed in the parautochthonous setting of the Eleonore $S \varnothing$ and Målebjerg tectonic windows (Slottet Formation and Målebjerg Formation formally erected above), are specifically excluded from the group because of the significantly different depositional context, located high on the craton in an attenuated Neoproterozoic - Lower Palaeozoic succession.

\section{Acknowledgements}

We are grateful to the referees, J.S. Peel and J.E. Repetski, whose perceptive comments greatly improved the manuscript.

\section{References}

Adams, P.J. \& Cowie, J.W. 1953: A geological reconnaissance of the region around the inner part of Danmarks Fjord, Northeast Greenland. Meddelelser om Grønland 111(7), 24 pp.

Andresen, A., Hartz, E. \& Vold, J. 1998: A late orogenic extensional origin for the infrastructural gneiss domes of the East Greenland Caledonides $\left(72^{\circ}-74^{\circ} \mathrm{N}\right)$. Tectonophysics 285, 353-369.

Clemmensen, L.B. \& Jepsen, H.F. 1992: Lithostratigraphy and geological setting of Upper Proterozoic shoreline-shelf deposits, Hagen Fjord Group, eastern North Greenland. Rapport Grønlands Geologiske Undersøgelse 157, 27 pp.

Collinson, J.D., Bevins, R.E. \& Clemmensen, L.B. 1989: Post-glacial mass flow and associated deposits preserved in palaeovalleys: the Late Precambrian Morænes $\varnothing$ Formation, North Greenland. Meddelelser om Grønland Geoscience 21, 26 pp.

Cooper, R.A. 1999: The Ordovician time scale - calibration of graptolite and conodont zones. Acta Universitas Carolinae Geologica 43(1/2), 1-4.

Cowie, J.W. \& Adams, P.J. 1957: The geology of the CambroOrdovician rocks of East Greenland. 1. Meddelelser om Grønland 153(1), 193 pp.

Crimes, T.P. 1992a: The record of trace fossils across the Proterozoic-Cambrian boundary. In: Lipps, J.H. \& Signor, P.W. (eds): Origin and early evolution of the Metazoa, 177-202. New York: Plenum Press.

Crimes, T.P. 1992b: Changes in the trace fossil biota across the Precambrian-Phanerozoic boundary. Journal of the Geological Society (London) 149, 637-646.

Encarnación, J., Rowell, A.J. \& Grunow, A.M. 1999: A U-Pb age for the Cambrian Taylor Formation, Antarctica: implications for the Cambrian timescale. Journal of Geology 107, 497504.
Escher, J.C. \& Jones, K.A. 1994: Caledonian thrusting and shearing in Lambert Land. In: Henriksen, N. (ed.): Express report: eastern North Greenland and North-East Greenland 1994, 2738. Unpublished report, Geological Survey of Greenland, Copenhagen.

Fortey, R.A., Harper, D.A.T., Ingham, J.K., Owen, A.W. \& Rushton, A.W.A. 1995: A revision of the Ordovician series and stages from the historical type area. Geological Magazine 132, 1530.

Fränkl, E. 1954: Vorläufige Mitteilung über die Geologie von Kronprins Christian Land (NE-Grönland). Meddelelser om Grønland 116(2), $85 \mathrm{pp}$

Fränkl, E. 1955: Weitere Beiträge zur Geologie von Kronprins Christian Land (NE-Grönland). Meddelelser om Grønland 103(7), $35 \mathrm{pp}$.

Friderichsen, J.D., Holdsworth, R.E., Jepsen, H.F. \& Strachan, R.A 1990: Caledonian and pre-Caledonian geology of Dronning Louise Land, North-East Greenland. Rapport Grønlands Geologiske Undersøgelse 148, 133-141.

Frykman, P. 1979: Cambro-Ordovician rocks of C.H. Ostenfeld Nunatak, northern East Greenland. In: Peel, J.S. (compiler): Lower Palaeozoic stratigraphy and palaeontology: shorter contributions. Rapport Grønlands Geologiske Undersøgelse 91, 125-132.

Haller, J. 1953: Geologie und Petrographie von West-Andrées Land und Ost-Frænkels Land (NE-Grönland). Meddelelser om Grønland 73 I (3), 174 pp.

Haller, J. 1961: The Carolinides: an orogenic belt of late Precambrian age in Northeast Greenland. In: Raasch, G.O. (ed.) Geology of the Arctic 1, 155-159. Toronto University Press.

Haller, J. 1971: Geology of the East Greenland Caledonides, 413 pp. London: Interscience.

Hambrey, M.J. \& Spencer, A.M. 1987: Late Precambrian glaciation of central East Greenland. Meddelelser om Grønland Geoscience 19, 50 pp.

Hambrey, M.J., Peel, J.S. \& Smith, M.P. 1989: Upper Proterozoic and Lower Palaeozoic strata in northern East Greenland. Rapport Grønlands Geologiske Undersøgelse 145, 103-108.

Harland, W.B., Hambrey, M.J. \& Waddams, P. 1993: The Vendian geology of Svalbard. Norsk Polarinstitut Skrifter 193, 150 pp.

Hartz, E. \& Andresen, A. 1995: Caledonian sole thrust of central East Greenland: a crustal scale Devonian extensional detachment. Geology 23, 637-640.

Henriksen, N. \& Higgins, A.K. 1976: East Greenland Caledonides. In: Escher, A. \& Watt, W.S. (eds): Geology of Greenland, 182246. Copenhagen: Geological Survey of Greenland.

Higgins, A.K. \& Leslie, A.G. 2000: Restoring thrusting in the East Greenland Caledonides. Geology 28, 1019-1022.

Higgins, A.K., Friderichsen, J.D. \& Thyrsted, T. 1981: Precambrian metamorphic complexes in the East Greenland Caledonides $\left(72^{\circ}-74^{\circ} \mathrm{N}\right)$ - their relationships to the Eleonore Bay Group and Caledonian orogenesis. Rapport Grønlands Geologiske Undersøgelse 104, 5-46.

Higgins, A.K., Ineson, J.R., Peel, J.S., Surlyk, F. \& Sønderholm, M. 1991: The Franklinian Basin in North Greenland. In: Peel, J.S. \& Sønderholm, M. (eds): Sedimentary basins of North Greenland. Bulletin Grønlands Geologiske Undersøgelse 160, 71139. 
Higgins, A.K., Leslie, A.G. \& Smith, M.P. 2001a: Neoproterozoic Lower Palaeozoic stratigraphical relationships in the marginal thin-skinned thrust belt of the East Greenland Caledonides: comparisons with the foreland in Scotland. Geological Magazine 138, 143-160.

Higgins, A.K., Smith, M.P., Soper, N.J., Leslie, A.G., Rasmussen, J.A. \& Sønderholm, M. 2001b: Caledonian inversion of the Hekla Sund Basin, eastern North Greenland: a pre-Iapetan rift sequence displaced across its rift shoulders during the Caledonian orogeny. Journal of the Geological Society (London) 158, 487-499.

Higgins, A.K. et al. 2004a: The foreland-propagating thrust architecture of the East Greenland Caledonides $72^{\circ}-75^{\circ} \mathrm{N}$. Journal of the Geological Society (London) 161, 1009-1026.

Higgins, A.K., Soper, N.J., Smith, M.P. \& Rasmussen, J.A. 2004b: The Caledonian thin-skinned thrust belt of Kronprins Christian Land, eastern North Greenland. In: Higgins, A.K. \& Kalsbeek, F. (eds): East Greenland Caledonides: stratigraphy, structure and geochronology. Geological Survey of Denmark and Greenland Bulletin 6, 41-56 (this volume).

Holdsworth, R.E. \& Strachan, R.A. 1991: Interlinked system of ductile strike slip and thrusting formed by Caledonian sinistral transpression in northeastern Greenland. Geology 19, 510513.

Hurst, J.M. 1984: Upper Ordovician and Silurian carbonate shelf stratigraphy, facies and evolution, eastern North Greenland. Bulletin Grønlands Geologiske Undersøgelse 148, 73 pp.

Hurst, J.M. \& McKerrow, W.S. 1981a: The Caledonian nappes of eastern North Greenland. Nature 290, 772-774.

Hurst, J.M. \& McKerrow, W.S. 1981b: The Caledonian nappes of Kronprins Christian Land, eastern North Greenland. Rapport Grønlands Geologiske Undersøgelse 106, 15-19.

Hurst, J.M. \& McKerrow, W.S. 1985: Origin of the Caledonian nappes of eastern North Greenland. In: Gee, D.G. \& Sturt, B.A. (eds): The Caledonide Orogen - Scandinavia and related areas, 1065-1069. London: John Wiley \& Sons.

Hurst, J.M. \& Surlyk, F. 1982: Stratigraphy of the Silurian turbidite sequence of North Greenland. Bulletin Grønlands Geologiske Undersøgelse 145, $121 \mathrm{pp}$.

Hurst, J.M., Jepsen, H.F., Kalsbeek, F., McKerrow, W.S. \& Peel, J.S. 1985: The geology of the northern extremity of the East Greenland Caledonides. In: Gee, D.G. \& Sturt, B.A. (eds): The Caledonide Orogen - Scandinavia and related areas, 10471063. London: John Wiley \& Sons.

Huselbee, M.Y. 1998: Late Cambrian to earliest Ordovician (Ibexian) conodont evolution and biogeography of Greenland and northwest Scotland, 296 pp. Unpublished Ph.D. thesis, University of Birmingham, UK.

Ineson, J.R., Peel, J.S. \& Smith, M.P. 1986: The Sjælland Fjelde Formation: a new Ordovician formation from eastern North Greenland. In: Peel, J.S. (ed.): North Greenland Lower Palaeozoic palaeontology and stratigraphy: short contributions. Rapport Grønlands Geologiske Undersøgelse 132, 27-37.

Katz, H.R. 1952: Ein Querschnitt durch die Nunatakzone Ostgrönlands (ca. $74^{\circ}$ n.B.). Ergebnisse einer Reise vom Inlandeis (in Zusammenarbeit mit den Expéditions Polaires Françaises von P.-E. Victor) ostwärts bis in die Fjordregion, ausgeführt im Sommer 1951. Meddelelser om Grønland 144(8), 65 pp.
Leslie, A.G. \& Higgins, A.K. 1998: On the Caledonian geology of Andrée Land, Eleonore $\$ \varnothing$ and adjacent nunataks $\left(73^{\circ} 30^{\prime}-\right.$ $74^{\circ} \mathrm{N}$ ), East Greenland. In: Higgins, A.K. \& Frederiksen, K.S. (eds): Caledonian geology of East Greenland $72^{\circ}-74^{\circ} \mathrm{N}$ : preliminary reports from the 1997 expedition. Danmarks og Grønlands Geologiske Undersøgelse Rapport 1998/28, 11-27.

Leslie, A.G. \& Higgins, A.K. 1999: On the Caledonian (and Grenvillian) geology of Bartholin Land, Ole Rømer Land and adjacent nunataks, East Greenland. In: Higgins, A.K. \& Frederiksen, K.S. (eds): Geology of East Greenland $72^{\circ}-75^{\circ} \mathrm{N}$, mainly Caledonian: preliminary reports from the 1998 expedition. Danmarks og Grønlands Geologiske Undersøgelse Rapport 1999/19, 11-26.

Miller, J.F. \& Kurtz, V.E. 1979: Reasssigment of the Dolomite Point Formation of East Greenland from the Middle Cambrian(?) to the Lower Ordovician based on conodonts. Geological Society of America Abstracts with Programs 10, 219 only.

Nathorst, A.G. 1901: Bidrag til nordöstra Grönlands geologi. Geologiska Föreningens i Stockholm Förhandlingar 23, 275306.

Peacock, J.D. 1956: The geology of Dronning Louise Land, N.E. Greenland. Meddelelser om Grønland 137(7), 38 pp.

Peacock, J.D. 1958: Some investigations into the geology and petrography of Dronning Louise Land, N.E. Greenland. Meddelelser om Grønland 157(4), 139 pp.

Peel, J.S. 1980: Geological reconnaissance in the Caledonian foreland of eastern North Greenland, with comments on the Centrum Limestone. Rapport Grønlands Geologiske Undersøgelse 99, 61-72.

Peel, J.S. 1985: Cambrian-Silurian platform stratigraphy of eastern North Greenland. In: Gee, D.G. \& Sturt, B.A. (eds): The Caledonide Orogen - Scandinavia and related areas, 10771094. London: John Wiley \& Sons.

Peel, J.S. \& Smith, M.P. 1988: The Wandel Valley Formation (EarlyMiddle Ordovician) of North Greenland and its correlatives. In: Peel, J.S. (ed.): Cambrian-Jurassic fossils, trace fossils and stratigraphy from Greenland. Rapport Grønlands Geologiske Undersøgelse 137, 61-92.

Peel, J.S. \& Vidal, G. 1988: Acritarchs from the Kap Holbæk Formation, North Greenland. In: Peel, J.S. (ed.): Cambrian-Jurassic fossils, trace fossils and stratigraphy from Greenland. Rapport Grønlands Geologiske Undersøgelse 137, 42 only.

Peel, J.S., Ineson, J.R., Lane, P.D. \& Armstrong, H.A. 1981: Lower Palaeozoic stratigraphy around Danmark Fjord, eastern North Greenland. Rapport Grønlands Geologiske Undersøgelse 106 21-27.

Pickerill, R.K. \& Peel, J.S. 1990: Trace fossils from the Lower Cambrian Bastion Formation of North-East Greenland. In: Peel, J.S. (ed.): Lower Cambrian trace fossils from Greenland. Rapport Grønlands Geologiske Undersøgelse 147, 5-43.

Rasmussen, J.A. \& Smith, M.P. 1996: Lower Palaeozoic carbonates in eastern North Greenland, and the demise of the 'Sæfaxi Elv nappe'. Bulletin Grønlands Geologiske Undersøgelse $\mathbf{1 7 2}$ 49-54.

Rasmussen, J.A. \& Smith, M.P. 2002: Conodont geothermometry and tectonic overburden in the northernmost East Greenland Caledonides. Geological Magazine 138, 687-698. 
Scrutton, C.T. 1975: Corals and stromatoporoids from the Ordovician and Silurian of Kronprins Christian Land, Northeast Greenland. Meddelelser om Grønland 171(4), 43 pp.

Skovsted, C.B. 2003: The Early Cambrian fauna of North-East Greenland. Unpublished thesis, Uppsala University, Sweden.

Smith, M.P. 1985: Ibexian-Whiterockian (Ordovician) conodont palaeontology of East and eastern North Greenland, 372 pp. Unpublished Ph.D. thesis, University of Nottingham, UK.

Smith, M.P. 1991: Early Ordovician conodonts of East and North Greenland. Meddelelser om Grønland Geoscience 26, 81 pp.

Smith, M.P. 2000: Cambro-Ordovician stratigraphy of Bjørnøya and North Greenland: constraints on tectonic models for the Arctic Caledonides and the Tertiary opening of the Greenland Sea. Journal of the Geological Society (London) 157, 459-470.

Smith, M.P. \& Bjerreskov, M. 1994: The Ordovician System in Greenland. Correlation chart and stratigraphic lexicon. International Union of Geological Sciences Special Publication 29A, $46 \mathrm{pp}$.

Smith, M.P. \& Peel, J.S. 1986: The age of the Danmarks Fjord Member, eastern North Greenland. In: Peel, J.S. (ed.): North Greenland Lower Palaeozoic palaeontology and stratigraphy: short contributions. Rapport Grønlands Geologiske Undersøgelse 132, 7-13.

Smith, M.P. \& Robertson, S. 1999a: The Nathorst Land Group (Neoproterozoic) of East Greenland - lithostratigraphy, basin geometry and tectonic history. In: Higgins, A.K. \& Frederiksen, K.S. (eds): Geology of East Greenland $72^{\circ}-75^{\circ} \mathrm{N}$, mainly Caledonian: preliminary reports from the 1998 expedition. Danmarks og Grønlands Geologiske Undersøgelse Rapport 1999/19, 127-143.

Smith, M.P. \& Robertson, S. 1999b: Vendian - Lower Palaeozoic stratigraphy of the parautchthon in the Målebjerg and Eleonore S $\varnothing$ windows. In: Higgins, A.K. \& Frederiksen, K.S. (eds): Geology of East Greenland $72^{\circ}-75^{\circ} \mathrm{N}$, mainly Caledonian: preliminary reports from the 1998 expedition. Danmarks og Grønlands Geologiske Undersøgelse Rapport 1999/19, 169-182.

Smith, M.P., Sønderholm, M. \& Tull, S.J. 1989: The Morris Bugt Group (Middle Ordovician - Silurian) of North Greenland and its correlatives. Rapport Grønlands Geologiske Unders $\varnothing$ gelse 143, 5-20.

Smith, M.P., Soper, N.J., Higgins, A.K. \& Rasmussen, J.A. 1999: Palaeokarst systems in the Late Proterozoic of eastern North
Greenland and their stratigraphic and tectonic significance. Journal of the Geological Society (London) 156, 113-124.

Smith, M.P., Higgins, A.K., Soper, N.J. \& Sønderholm, M. 2004: The Neoproterozoic Rivieradal Group of Kronprins Christian Land, eastern North Greenland. In: Higgins, A.K. \& Kalsbeek, F. (eds): East Greenland Caledonides: stratigraphy, structure and geochronology. Geological Survey of Denmark and Greenland Bulletin 6, 29-39 (this volume).

Sønderholm, M. \& Jepsen, H.F. 1991: Proterozoic basins of North Greenland. In: Peel, J.S. \& Sønderholm, M. (eds): Sedimentary basins of North Greenland. Bulletin Grønlands Geologiske Undersøgelse 160, 49-69.

Stouge, S., Boyce, D.W., Christiansen, J., Harper, D.A.T. \& Knight, I. 2001: Vendian - Lower Ordovician stratigraphy of Ella $\varnothing$, North-East Greenland: new investigations. Geology of Greenland Survey Bulletin 189, 107-114.

Stouge, S., Boyce, D.W., Christiansen, J.L., Harper, D.A.T. \& Knight, I. 2002: Lower-Middle Ordovician stratigraphy of North-East Greenland. Geology of Greenland Survey Bulletin 191, 117125.

Strachan, R.A., Friderichsen, J.D., Holdsworth, R.E. \& Jepsen, H.F. 1994: Regional geology and Caledonian structure, Dronning Louise Land, North-East Greenland. In: Higgins, A.K. (ed.): Geology of North-East Greenland. Rapport Grønlands Geologiske Undersøgelse 162, 71-76.

Swett, K. \& Smit, D.E. 1972: Paleogeography and depositional environments of the Cambro-Ordovician shallow marine facies of the North Atlantic. Bulletin of the Geological Society of America 83, 3223-3248.

Toula, F. \& Lenz, O. 1874: Geologie Ostgrönlands zwischen dem 73. und $76 .^{\circ}$ nordl. Br. In: Geographisches Gesellschaft in Bremen: Die zweite deutsche Nordpolarfahrt in den Jahren 1869 und 1870. 2, 475-496.

Tucker, R.D. \& McKerrow, W.S. 1995: Early Paleozoic chronology: a review in light of new U-Pb ages from Newfoundland and Britain. Canadian Journal of Earth Sciences 32, 368-379.

Wenk, E. 1961: On the crystalline basement and the basal part of the pre-Cambrian Eleonore Bay Group in the southwestern part of Scoresby Sund. Meddelelser om Grønland 168(1), 54 pp.

Wordie, J.M. 1927: The Cambridge expedition to East Greenland in 1926. Appendix V. Geology. Geographical Journal 70, 252253. 